Article

\title{
Radiation Synthesis of Selenium Nanoparticles Capped with $\beta$-Glucan and Its Immunostimulant Activity in Cytoxan-Induced Immunosuppressed Mice
}

\author{
Nguyen Thi Dung ${ }^{1,2}$, Tran Duc Trong ${ }^{1}$, Nguyen Thanh Vu ${ }^{1}{ }^{1}$, Nguyen Trong Binh ${ }^{1}$, Tran Thi Le Minh ${ }^{2}$ \\ and Le Quang Luan $1, *$ (D) \\ 1 Biotechnology Center of Ho Chi Minh City, Ho Chi Minh City 700000, Vietnam; \\ thuydung9810@gmail.com (N.T.D.); trong21052011@gmail.com (T.D.T.); ntvu1412@gmail.com (N.T.V.); \\ nguyentrongbinhensh@yahoo.com (N.T.B.) \\ 2 Faculty of Biologinal Sciences, Nong Lam University, Ho Chi Minh City 700000, Vietnam; \\ ttlminh@hcmuaf.edu.vn \\ * Correspondence: lequangluan@gmail.com
}

check for updates

Citation: Dung, N.T.; Trong, T.D.; Vu, N.T.; Binh, N.T.; Minh, T.T.L.; Luan, L.Q. Radiation Synthesis of Selenium Nanoparticles Capped with $\beta$-Glucan and Its Immunostimulant Activity in Cytoxan-Induced Immunosuppressed Mice.

Nanomaterials 2021, 11, 2439. https:// doi.org/10.3390/nano11092439

Academic Editor: Thierry Rabilloud

Received: 18 August 2021

Accepted: 16 September 2021

Published: 18 September 2021

Publisher's Note: MDPI stays neutral with regard to jurisdictional claims in published maps and institutional affiliations.

Copyright: (C) 2021 by the authors Licensee MDPI, Basel, Switzerland. This article is an open access article distributed under the terms and conditions of the Creative Commons Attribution (CC BY) license (https:/ / creativecommons.org/licenses/by/ $4.0 /)$.
Abstract: Selenium nanoparticles (SeNPs) with diameters from 64.8 to $110.1 \mathrm{~nm}$ were successfully synthesized by $\gamma$-irradiation of solutions containing $\mathrm{Se}^{4+}$ and water-soluble yeast $\beta$-glucan. The size and size distribution of SeNPs were analyzed by dynamic light scattering (DLS). Analytical X-ray diffraction (XRD) pattern results confirmed the crystal structure of the Se nanoparticles and Fourier transform infrared (FTIR) spectroscopy revealed that $\beta$-glucan could interact with SeNPs through steric (Se ... O) linkages leading to a homogeneous and translucent solution state for 60 days without any precipitates. In vivo tests in cytoxan-induced immunosuppressed mice revealed that the daily supplementation of SeNPs/ $\beta$-glucan at concentrations of $6 \mathrm{mg}$ per $\mathrm{kg}$ body weight of tested mice significantly stimulated the generation of cellular immune factors (white blood cells, neutrophil, lymphocyte, B cells, CD4+ cells, CD34+ cells and natural killer cells) and humoral immune indexes (IgM, IgG, TNF- $\alpha$, IFN- $\gamma$ and IL-2) in peripheral blood, bone marrow and spleen of the immunosuppressed mice. The obtained results indicated that radiation-synthesized SeNPs/ $\beta$-glucan may be a candidate for further evaluation as an agent for the prevention of immunosuppression in chemotherapy.

Keywords: $\gamma$-irradiation; selenium nanoparticles; immunostimulant; immunosuppressed mice; water-soluble $\beta$-glucan

\section{Introduction}

Selenium (Se) is an trace element essential for maintaining the health of mammalian animals due to its broad functions in biologic systems such as antioxidant, immune modulation, cancer prevention and antiviral activities [1-3]. However, the margin between the lowest acceptable intake level and the toxic level of selenium compounds is extremely narrow [4] and the toxicity depends on its chemical form. Selenate $\left(\mathrm{Se}^{+6}\right)$, selenite $\left(\mathrm{Se}^{+4}\right)$ and selenide $\left(\mathrm{Se}^{-2}\right)$ are commonly oxidation states of this metalloid element in the environment. Generally, selenium nanoparticles (SeNPs) are prepared by reduction of higher oxidation states to the $\mathrm{Se}^{0}$ form [5-7]. SeNPs have attracted widespread attention due to their excellent bioavailability, high bioactivity and low toxicity compared to their inorganic and organic counterparts [7-9]. Zang et al. [10], and Zhai et al. [11] reported that the $\mathrm{LD}_{50}$ of SeNPs in mice was about $91.2-258.2 \mathrm{mg}$ Se per $\mathrm{kg}$ body weight and these values were much lower than that of methylselenocysteine $\left(22.0 \mathrm{mg} \mathrm{kg}^{-1}\right)$ and $\mathrm{H}_{2} \mathrm{SeO}_{3}(14.6 \mathrm{mg}$ $\mathrm{kg}^{-1}$ ). It is reported that SeNPs have higher antioxidant, immunostimulant, anticancer, antiviral and antibacterial effects compared to their ionic forms [12]. The in vivo immunostimulatory effect of biogenic SeNPs on a $4 \mathrm{~T} 1$ breast cancer model mice carried out by 
Yazdi et al. [13,14] demonstrated that cellular immunomodulatory components such as granzyme B, IL-12, IFN- $\gamma$, and IL-2 were significantly increased in mice treated with both SeNPs and 4T1 cells in comparison to other groups, while the levels of TGF- $\beta$ were decreased in the tested mice. Jia et al. [15] also reported that biosynthesized SeNPs stabilized in lentinan (a branched $\beta-(1,3)$-D-glucan extracted from the fruiting bodies of Lentinus edodes) showed higher antitumor activity on HeLa cells than that of a lentinan sample. Recently, Duy et al. [16] reported that SeNPs/oligochitosan synthesized by $\gamma$-irradiation could restore the white blood cell levels in irradiated mice. However, to the best of our knowledge, the immunostimulant effect of SeNPs on immunosuppressed mice has not been studied.

So far, SeNPs have been synthesized from ionic selenium solutions by different methods, such as biological [13], chemical [15] and irradiation methods [7,16]. According to Hien et al. [7], $\gamma$-ray irradiation could be considered a more effective method than others thanks to several advantages such as, the reaction can be performed at room temperature, high-purity SeNPs can be obtained due to the absence of reductant residues, the SeNP size can be easily controlled by adjusting the dose and dose rate, and large-scale production is possible and finally, they are more suited for the medicinal, surgical and pharmaceutical applications.

On the other hand, the stabilizer used also plays an important role in fabrication of SeNP products. Menon et al. [17]. reported that selenium nanoparticles with mean molecular size measurements ranging from $24 \mathrm{~nm}$ to $200 \mathrm{~nm}$ can be obtained when conjugated with bovine serum albumin (BSA), L-cysteine, glucose, sucrose, chitosan and sulfated polysaccharides as stabilizer in the redox framework. Several biopolymers including curcumin [18], glutathione [19], protein BSA [20,21], galic acid [22] and folic acid [23] have been used to prepare capped SeNPs to enhance to biocompatibility of this product. Several researchers have used natural polysaccharides for stabilizing SeNP products due to their unique properties including excellent biocompatibility, biodegradability, stability, and non-toxicity $[7,11,15,16,22,24,25]$. According to Zhang et al. [26] polysaccharides can be considered an appropriate template for the synthesis of selenium nanoparticles compared to phenolics and proteins because proteins are prone to enzymatic degradation and require high temperatures and phenolics are auto-oxidized and become aggregated at the $\mathrm{pH}$ of the stomach. Among naturally-originated polysaccharides, branched $\beta-(1,3)$-D-glucan isolated from yeast cell walls has been widely applied in the food and pharmaceutical industries [27-29]. Since the native yeast $\beta$-glucan is high molecular weight and water-insoluble properties, the degradation of this product to a lower molecular weight and water-soluble form is more suitable for applications [30-33], including nanoparticle stabilization.

Therefore, the aim of present study was to apply the $\gamma$-ray irradiation method for the synthesis of SeNPs stabilized in water-soluble yeast. The immunostimulant effect of the SeNPs / $\beta$-glucan product was also investigated in cytoxan-induced immunosuppressed mice for evaluation of its potential application as an immunosuppressive nutraceutical.

\section{Materials and Methods}

\subsection{Materials}

Pure selenium dioxide $\left(\mathrm{SeO}_{2}\right)$ and cytoxan (CTX) were supplied by Sigma- Aldrich (St. Louis, MO, USA). ELISA Kits (Mouse IgM-ab133047; Mouse IgG-ab151276; Mouse IL-2-ab223588, Mouse Interferon gamma-ab100689) and Mouse TNF alpha-ab208348) were products of Abcam (Cambridge, UK). Yeast water-soluble $\beta$-glucan $(1-3,1-6)$ with $\mathrm{Mw}$ $\sim 25 \mathrm{kDa}$ was a gift from Biomaterials and Nano Technology Department, Biotechnology Center of Ho Chi Minh City (Vietnam). Adult BALB/c mice were provided by the Stem Cell Institute (Vietnam National University, Ho Chi Minh City, Vietnam). Other pure-grade chemicals were used, and distilled water was used throughout the experiments. 


\subsection{Synthesis of SeNPs/ $\beta$-Glucan by Gamma Co-60 Irradiation}

Solutions of $40,60,80,100$ and $120 \mathrm{ppm} \mathrm{Se}^{4+}$ in $2 \% \beta$-glucan were prepared by mixing appropriate volumes from $800 \mathrm{ppm} \mathrm{Se}{ }^{4+}$ and $2 \% \quad \beta$-glucan stock solutions. $\mathrm{pH}$ of $\mathrm{Se}^{4+} / \beta$-glucan solution was adjusted to $5.0,6.0,7.0$ and 8.0 by $0.5 \% \mathrm{NH}_{4} \mathrm{OH}$ solution. Then, $100 \mathrm{~mL}$ of the prepared $\mathrm{Se}^{4+} / \beta$-glucan solutions of were put into glass bottles with plastic caps and irradiated in a Gamma Co-60 Chamber model GC5000 (BRIT, Munbai, India) at a dose range of 4-14 kGy and dose rate of 2.5-10.0 $\mathrm{kGy} \mathrm{h}^{-1}$ for the synthesis of SeNPs / $\beta$-glucan solutions.

\subsection{Preparation of SeNPs/ $\beta$-Glucan Powder}

The SeNPs / $\beta$-glucan solution from $80 \mathrm{ppm} \mathrm{Se}^{4+}$ in $2 \% \beta$-glucan sample was used to prepare SeNPs powder by spray drying on spray dryer model B290 (Buchi, St. Gallen, Switzerland) and by freeze drying in freeze dryer model GAMMA 1-16 LSCplus (Christ, Lower Saxony, Germany). The SeNPs powder was also prepared by coagulation. For coagulation of SeNPs / $\beta$-glucan, ethanol ( 9 volumes) was mixed with 1 volume of SeNPs / $\beta$ glucan solution. The resulting SeNPs/ $\beta$-glucan coagulate was filtered and washed several times with ethanol and dried in a forced air oven at $60^{\circ} \mathrm{C}$.

\subsection{Analysis of $\mathrm{Se}^{4+}$ in Irradiated Samples}

To determine the remain content of $\mathrm{Se}^{4+}$ ion in $\mathrm{Se}^{4+} / \beta$-glucan solution after irradiation, irradiated $\mathrm{Se}^{4+} / \beta$-glucan solutions were centrifuged at $111,400 \times g$ for $30 \mathrm{~min}$ in a model Optima MAX-XP ultracentrifuge (Beckman Coulter, Brea, CA, USA) for separation of SeNPs. The content of $\mathrm{Se}^{4+}$ ion in the supernatant was analyzed by a spectrophotometric method using Azure B as a chromogenic regent as described by Mathew and Narayana [34].

\subsection{Characterization of SeNPs/B-Glucan}

The particle size, size distribution and zeta potential of SeNPs solutions were characterized on a Malvern Zetasizer model ZEN5600 (Malvern, Worcestershire, UK) using the Zetasizer Softwave V.7.12. The size and size distribution of the SeNPs/ $\beta$-glucan were also further determined from TEM images obtained on a model JEM1010 transmission electron microscope (TEM, JEOL, Tokyo, Japan) and statistically calculated from about 300 particles, typically for the $80 \mathrm{ppm}$ SeNPs sample synthesized at $8 \mathrm{kGy}$ and dose rate of $10 \mathrm{kGy} \mathrm{h}^{-1}$.

The crystalline structure of SeNPs was characterized using an X'Pert PRO-powder diffractometer (Malvern) with parafocusing Bragg-Brentano geometry using $\mathrm{CuK} \alpha$ radiation $(\lambda \theta=1.5418 \AA, \mathrm{U}=40 \mathrm{kV}, \mathrm{I}=30 \mathrm{~mA})$. SeNPs $/ \beta$-glucan sample was prepared by centrifuging the sample at $111,400 \times \mathrm{g}$ for $30 \mathrm{~min}$ at $10{ }^{\circ} \mathrm{C}$. The sample was dried at room temperature to get the powder form for analysis. Data were scanned with the ultrafast detector $X^{\prime}$ Celerator or with a scintillator detector equipped with a secondary curved monochromator over the angular range $5-60^{\circ}(2 \theta)$ with $0.02^{\circ}(2 \theta)$ and $0.3 \mathrm{~s} \mathrm{step}^{-1}$. The software package HighScore Plus was used for data analysis.

Fourier transform infrared (FTIR) spectroscopy analysis was performed to the reveal functional groups involved the synthesis of $\beta$-glucan and SeNPs / $\beta$-glucan. The spectra were recorded in the region between 4000 and $400 \mathrm{~cm}^{-1}$ with 128 scans at a resolution of $4 \mathrm{~cm}^{-1}$ using a FTIR-8100A spectrophotometer (Shimadzu, Kyoto, Japan) linked with a Shimadzu DR-8030 computer system. Samples were prepared in a KBr pellet formed by well-dried mixtures of freeze-dried samples ( $\beta$-glucan and 80ppm-SeNPs / $\beta$-glucan) and $100 \mathrm{mg}$ of $\mathrm{KBr}$.

The stability of SeNPs/ $\beta$-glucan solution stored at various temperature conditions within 60 days and the change of particle size and size distribution in powder products were evaluated by dynamic light scattering (DLS).

\subsection{Animal Experimental Design}

Fifty-four 12-week-old male BALB/c mice with body weight about 25-30 g were raised in cages at the standard room of Stem Cell Institute followed the guidelines of the 
Association for Assessment and Accreditation of Animal Care International (AAALAC). After two weeks being raised at $22^{\circ} \mathrm{C}$ and 12-h light-dark cycle, mice were divided into 2 groups. A group of 9 mice was used for normal control (N-Ctrl). Another group of 45 mice were subjected to immunosuppression by intraperitoneal injection of CTX with a dose of $100 \mathrm{mg} \mathrm{kg}^{-1}$ body weight for 3 consecutive days [35,36]. Then, the CTX-treated mice were randomly divided into five groups (nine mice per group) for experiment as follows: mice in the control group (CTX-Ctrl) were received only distilled water, while mice in other four groups were orally supplied with 0 (only $\beta$-glucan without SeNPs), 2, 4 and $6 \mathrm{mg}$ SeNPs / $\beta$-glucan product daily per a $\mathrm{kg}$ body weight for 14 days. After supplying with SeNPs / $\beta$-glucan for 14 days, mice in each group were killed through a cervical dislocation method and used for analysis.

\subsection{Spleen Index Determination}

The spleen was dissected and weighed. The spleen index was calculated by the following equation [25]: Spleen index $\left(\mathrm{mg} 10 \mathrm{~g}^{-1}\right)=[$ Spleen weight $(\mathrm{mg})] \times[$ Animal body weight $(\mathrm{g})]^{-1} \times 10$.

\subsection{Analysis of Cytokine and Immunoglobulin Indexes in Serum and Spleen}

For analysis of cytokine and immunoglobulin indexes in serum, all blood of tested mice in each group was collected and centrifuged at $1438 \times g$ for 10 min to collect serum. The immune parameters including IgG, IgM, IL-2, IFN- $\gamma$ and TNF- $\alpha$ in collected serum were determined by suitable ELISA Kits.

For spleen samples, all spleens of each tested mice were collected and conducted according to the method described by Han et al. [36]. Briefly, the collected spleens were soaked with a $70 \%$ ethanol solution within $3 \mathrm{~min}$ for sterilization and then washed with Hank's buffer solution twice under sterile condition. A portion of $100 \mathrm{mg}$ of spleen tissue was homogenized in $2 \mathrm{~mL}$ physiological saline solution at $4{ }^{\circ} \mathrm{C}$ before centrifuging at $1438 \times g$ for 15 min to collect the supernatant. The concentration of IL-2, IFN- $\gamma$, TNF- $\alpha$, IgG and IgM in spleen was determined in the same way as in serum above.

\subsection{Determination of Cellular Immunity}

The ratios of hematopoietic progenitor cells (CD34-ab81289 for primary antibody and ab150077 for secondary antibody), T-CD4 + cells (CD4-ab269349 antibody conjugated with fluorescein isothiocyanate), B cells (CD20-ab64088 for primary antibody and ab150077 for secondary antibody), natural killer (NK) cells (CD161-ab137059 for primary antibody and ab150077 for secondary antibody), neutrophils (clone 7/4 recognizes the Ly-6B.2 antigen in 129J-ab53453 antibody conjugated with fluorescein isothiocyanate), WBC and lymphocyte which were gated base on two optical detectors: forward scatter (FSC) and side scatter (SSC) in peripheral blood and bone marrow of tested mice were determined using a model FACS ARIA III flow cytometer (BD Science, Franklin Lakes, NJ, USA).

For peripheral blood samples, all red blood cells in blood were lysed by a red blood cell lysis buffer and then washed once with 45 mL Dulbecco's PBS in 2\% fetal bovine serum (FBS). The supernatant was aspirated, and pellets were incubated in a 1\% bovine serum albumin (BSA) blocking solution before resuspending in phosphate buffered saline (PBS). Suspended cells were stained for 30 min with the antibodies, washed twice with PBS, and recovered via centrifugation. Flow cytometry was performed using a BD FACSAria ${ }^{\mathrm{TM}}$ III cell sorter.

In case of bone marrow samples, femoral segments from shin bones of tested mice were collected for use. The bone segments were cut and then the cell culture medium (DMEM/F12 supplemented with 10\% FBS and 1\% penicillin-streptomycin) was pumped into the bone marrow three times by a $1 \mathrm{~mL}$-needle. All the cell suspension was transferred to a clean centrifuge tube and centrifuge at $734 \times g$ for $10 \mathrm{~min}$ to obtain bone marrow and treat in the way of peripheral blood sample before analyzing by flow cytometry. 
All tests on the mice were conducted according to the ethical guidelines for animal research of (AAALAC) and approved by the Scientific Council of the Biotechnology Center of Ho Chi Minh City (approval No.: 380/QĐ-CNSH). All experiments were repeated three times. Data were statistically analyzed using the ANOVA test. The least significant difference (LSD) at a $5 \%$ probability level was used to compare the mean values and the standard deviations were also calculated.

\section{Results and Discussion}

\subsection{Characteristics of Radiation Synthesized SeNPs}

SeNPs have been already synthesized by $\gamma$-irradiation using oligochitosan as a stabilizer [16]. In this study, solutions containing various $\mathrm{Se}^{4+}$ concentrations in water-soluble $\beta$-glucan with $\mathrm{Mw} \sim 25 \mathrm{kDa}$ were irradiated for the preparation of SeNPs. It can be seen from Figure 1 that the doses required for complete reduction of $\mathrm{Se}^{4+}$ into $\mathrm{Se}^{0}$ (the saturation dose for complete reduction of $\mathrm{Se}^{4+}$ ) in the solutions containing 40, 60, 80, 100 and $120 \mathrm{ppm}$ $\mathrm{Se}^{4+}$ were found to be $4,6,8,10$ and $12 \mathrm{kGy}$, respectively. This can be visualized by the color change from light yellow to orange-red of SeNPs / $\beta$-glucan solutions after irradiation (see Figure 1).

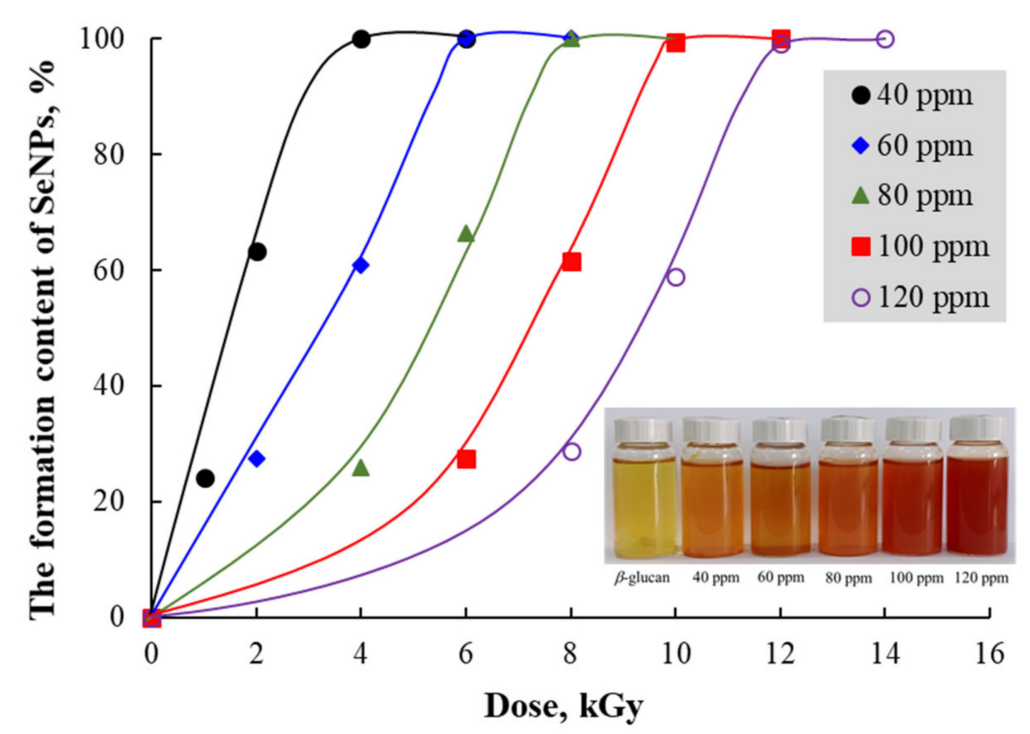

Figure 1. The saturated dose for radiation synthesis of SeNPs/ $\beta$-glucan samples with various $\mathrm{Se}^{4+}$ concentration.

Several papers have reported that $\mathrm{Se}^{4+}$ concentration was one of the major parameters affecting the particle size and size distribution of SeNPs products $[15,16]$. The influence of $\mathrm{Se}^{4+}$ concentration on the particle size and size distribution of SeNPs / $\beta$-glucan synthesized by the $\gamma$-irradiation method is presented in Figure 2. The results of a dynamic light scattering (DLS) analysis clearly showed that the particle size of SeNPs increased with the increase of concentration of $\mathrm{Se}^{4+}$ in the irradiated samples. Particularly, particle sizes of SeNPs ranging from 64.8 to $110.1 \mathrm{~nm}$ were determined in irradiated samples containing 40-120 ppm Se ${ }^{4+}$, respectively. These results were in good agreement with those reported by Jia el al. [15]. In addition, the particle size distribution found to display a Gaussian distribution in all products. Among them, the product obtained from the irradiated sample containing $80 \mathrm{ppm} \mathrm{Se}^{4+}$ showed the narrowest distribution. 

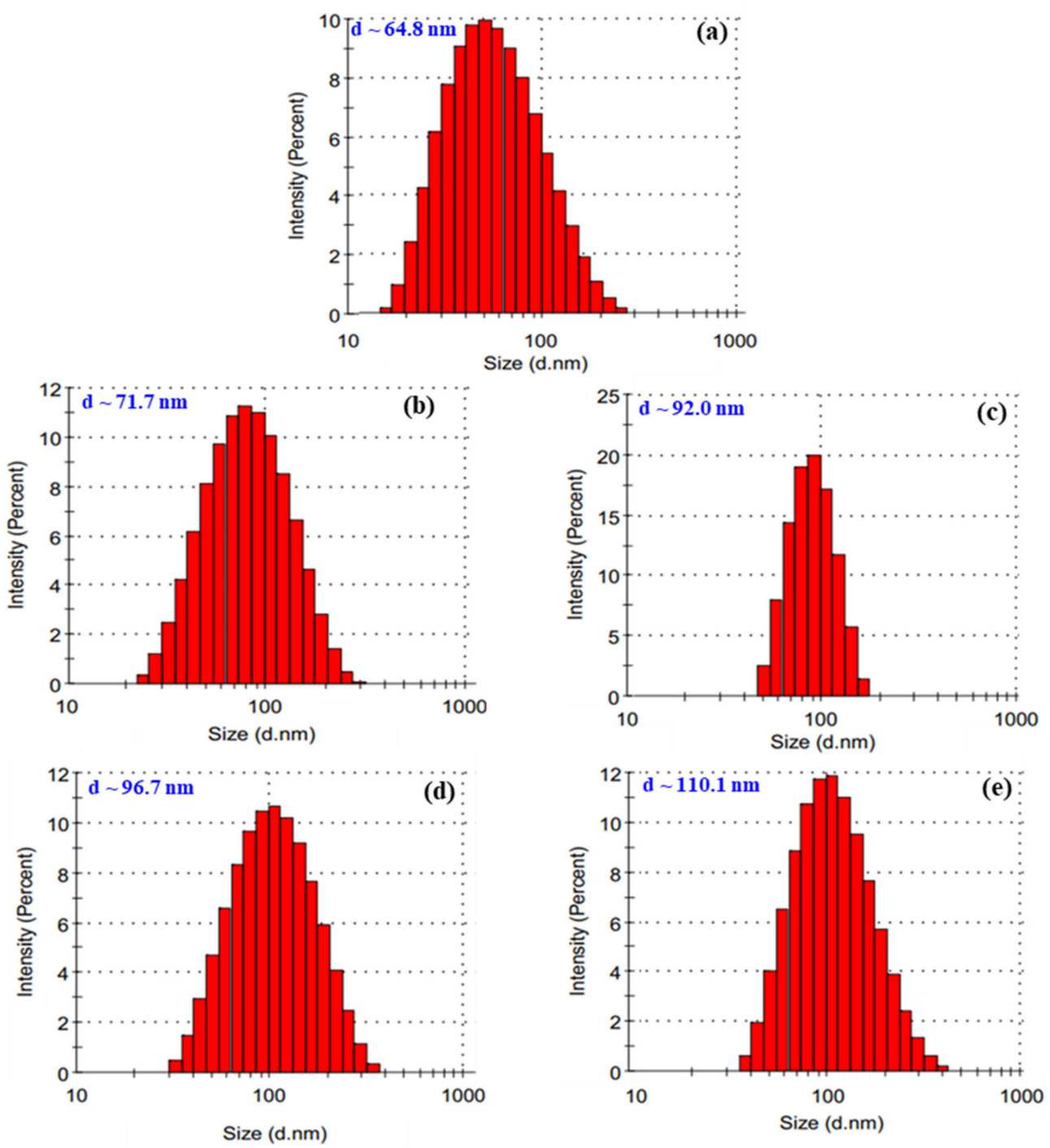

Figure 2. Particle size and size distribution of SeNPs / $\beta$-glucan samples with various $\mathrm{Se}^{4+}$ concentrations syntheiszed by irradiation. (a) 40 ppm; (b) 60 ppm; (c) 80 ppm; (d) 100 ppm and (e) 120 ppm.

On the other hand, the results in Figure 3 also show the effect of the $\mathrm{pH}$ on the particle size and its distribution. It can be clearly seen that the average particle size of SeNPs in the products was not significantly reduced, but the size distribution was greatly increased by an increase in the $\mathrm{pH}$ level. The reason may be due to an increase of the swelling of $\beta$-glucan molecules in solution with higher $\mathrm{pH}$, leading to a looser network structure of the stabilizer. Jia et al. [15] reported that lentinan (branched $\beta$-(1,3)-D-glucan isolated from the fruiting bodies of Lentinus edode) played an important role in the dispersion of SeNPs in solution. 

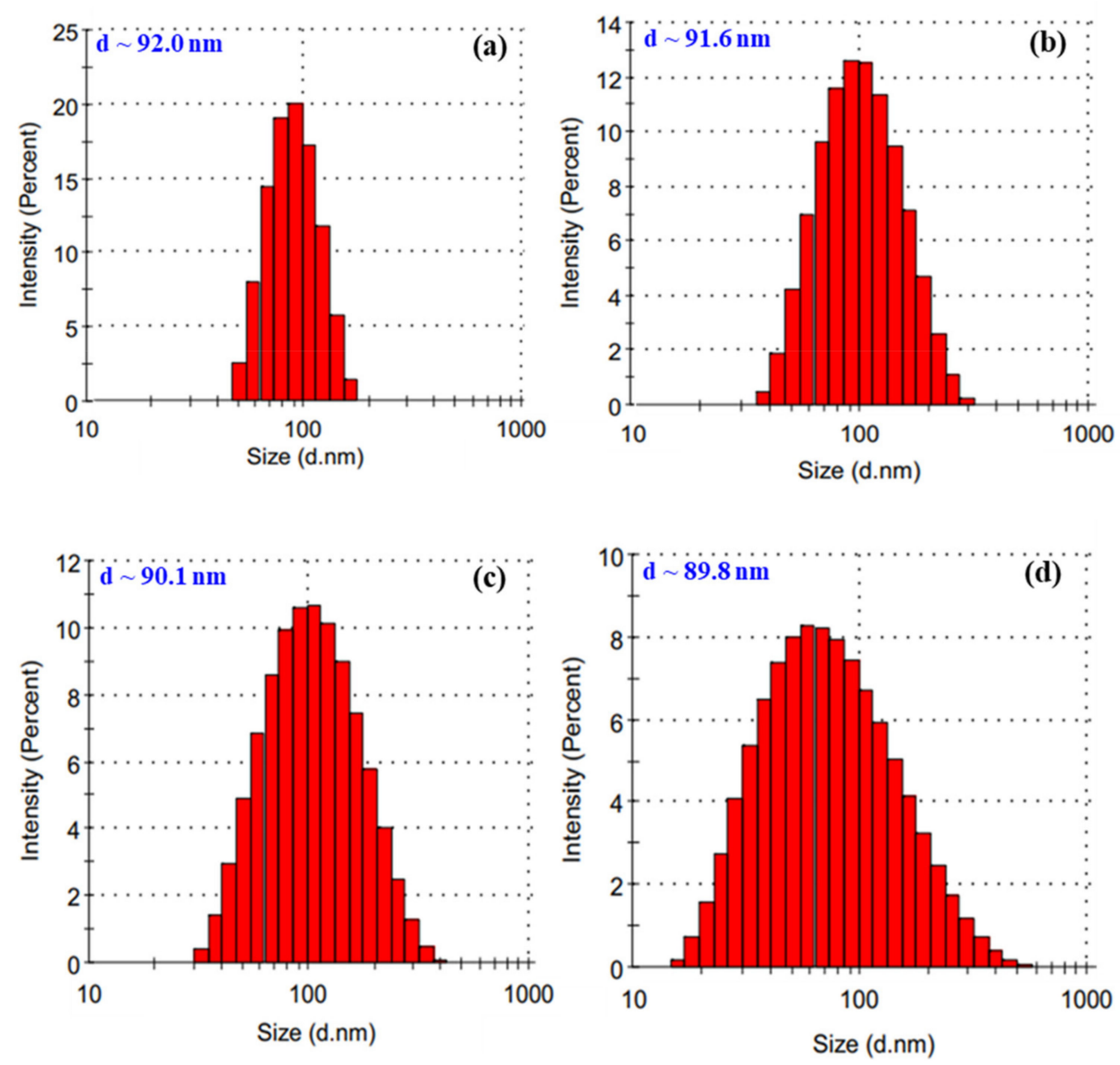

Figure 3. Particle size and size distribution of SeNPs / $\beta$-glucan samples of $80 \mathrm{ppm}$ SeNPs synthesized in various $\mathrm{pH}$ conditions. (a) $\mathrm{pH} \sim 5$; (b) $\mathrm{pH} \sim 6$; (c) $\mathrm{pH} \sim 7$ and (d) $\mathrm{pH} \sim 8$.

The dose rate has been reported to have significant effect on the particle size of nanocolloidal products synthesized by irradiation [37,38]. Hien et al. [37] reported that an increase of dose rate from 0.5 to $5 \mathrm{kGy} \mathrm{h}^{-1}$ led to a corresponding decrease of the size of gold nanoparticles (AuNPs) from 9.5 to $5 \mathrm{~nm}$, respectively. Khoa et al. [38] informed that a higher dose rate led to a narrower size distribution of AuNPs. In the present study, it can be seen from Figure 4 that the particle size of SeNPs was decreased by the increase of dose rate. In addition, the size distribution of SeNPs also became narrower when the sample was irradiated with a higher dose rate. The reason for this phenomenon is the competition between the adsorption of $\mathrm{Se}^{4+}$ onto the resultant selenium clusters and the reduction reaction of $\mathrm{Se}^{4+} \rightarrow \mathrm{Se}^{3+} \rightarrow \mathrm{Se}^{2+} \rightarrow \mathrm{Se}^{1+} \rightarrow \mathrm{Se}^{0}$ to form new clusters. At a high dose rate, the reduction reaction is predominant and therefore there are many new clusters leading to smaller SeNPs formed. On the contrary, at a low dose rate the adsorption of $\mathrm{Se}^{4+}$ onto clusters is predominant; therefore, SeNPs will be larger. 

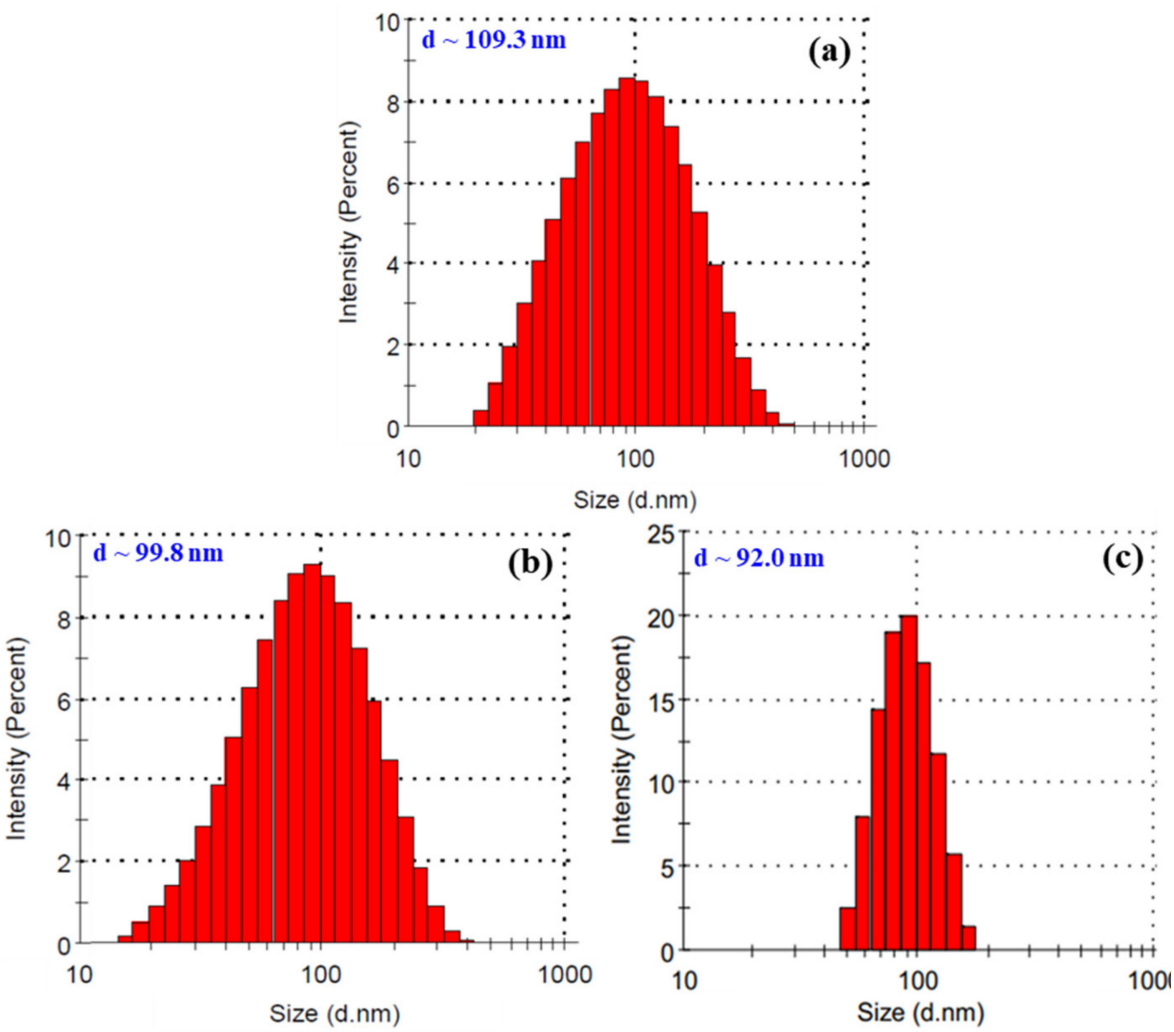

Figure 4. Particle size and size distribution of SeNPs / $\beta$-glucan samples synthesized at dose rates of 2.5 (a), 5 (b) and $10 \mathrm{kGy} \mathrm{h}^{-1}$ (c).

The above results suggested that the SeNPs / $\beta$-glucan synthesized by irradiation of solution containing $80 \mathrm{ppm} \mathrm{Se}^{4+}$ in $\mathrm{pH} \sim 5$ at $8 \mathrm{kGy}$ with dose rate of $10 \mathrm{kGy} \mathrm{h}^{-1}$ is the suitable product selected for further characterization and investigation in mice as well. Results from Figure $5 \mathrm{c}$ indicate that the particle size of SePNs in this product measured by TEM was about $65.3 \mathrm{~nm}$ and smaller than that estimated by DLS. According to Souza, et al. [39], the DLS mean size was approximately $20 \%$ higher than the TEM mean size because DLS gives a hydrodynamic size, which is the size of the nanoparticle plus the liquid layer around the particles, but the size measured by TEM represents the actual size of the nanoparticle. In addition, the zeta potential of this product was about $-6.9 \mathrm{mV}$ (Figure $5 b$ ). This factor is one of the key particle properties that can affect the particle stability as well as its cell adhesion. These results are in good agreement with those obtained for SeNPs synthesized by a chemical method using $\beta$-glucan isolated from the fruiting bodies of Lentinus edodes as stabilizer [15]. 

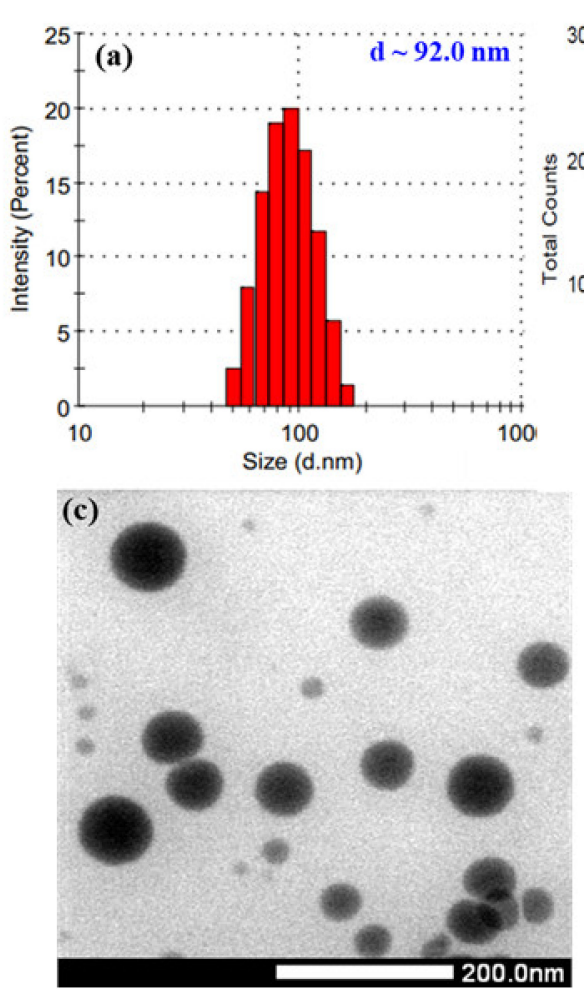

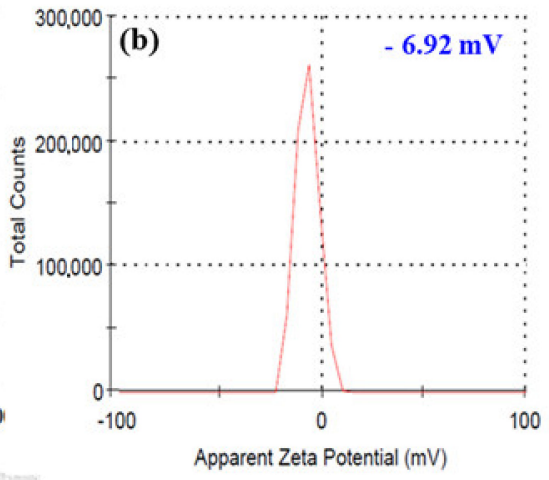

(d)

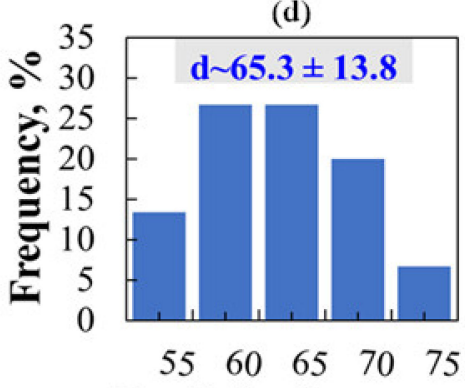

Particile size, $\mathbf{n m}$

Figure 5. Particle size, size distribution (a) and zeta potential (b) TEM image (c) and size distribution histogram (d) of SeNPs / $\beta$-glucan synthesized by gamma irradiation at dose of $8 \mathrm{kGy}$ and dose rate of $10 \mathrm{kGy} \mathrm{h}^{-1}$.

Figure 6 shows the FTIR spectra of SeNPs/ $\beta$-glucan prepared from the solution containing 80 ppm Se ${ }^{4+}$ and $2 \%$ water-soluble $\beta$-glucan and water-soluble $\beta$-glucan. It can be seen from Figure 6 that all typical absorption peaks of $\beta$-glucan and SeNPs / $\beta$-glucan including - $\mathrm{OH}\left(3383 \mathrm{~cm}^{-1}\right),-\mathrm{CH}_{2}\left(2986 \mathrm{~cm}^{-1}\right),-\mathrm{C}=\mathrm{O}\left(1640 \mathrm{~cm}^{-1}\right), \mathrm{C}-\mathrm{O}-\mathrm{C}\left(1156 \mathrm{~cm}^{-1}\right)$ and $\beta$-D-glucan $\left(890 \mathrm{~cm}^{-1}\right)$ are present, however, the typical peaks assigned for $-\mathrm{OH}$ and $-\mathrm{C}=\mathrm{O}$ were significantly shifted from $3383 \mathrm{~cm}^{-1}$ to $3390 \mathrm{~cm}^{-1}$ and from $1640 \mathrm{~cm}^{-1}$ to 1647 $\mathrm{cm}^{-1}$ in the spectrum of SeNPs / $\beta$-glucan, respectively. The changes of $-\mathrm{OH}$ group and $\mathrm{C}=\mathrm{O}$ linkage vibrations of $\beta$-glucan in SeNPs $/ \beta$-glucan spectrum may be attributed to the hydrogen bond-like interactions between $\beta$-glucan molecules and SeNPs and indicative of a complexation between selenium and $\beta$-glucan molecules in the product via the steric linkage (Se ... O). Our results are in good agreement with those of SeNPs/dextran reported by Hien et al. [7] and SeNPs/oligochitosan reported by Duy et al. [16]. 


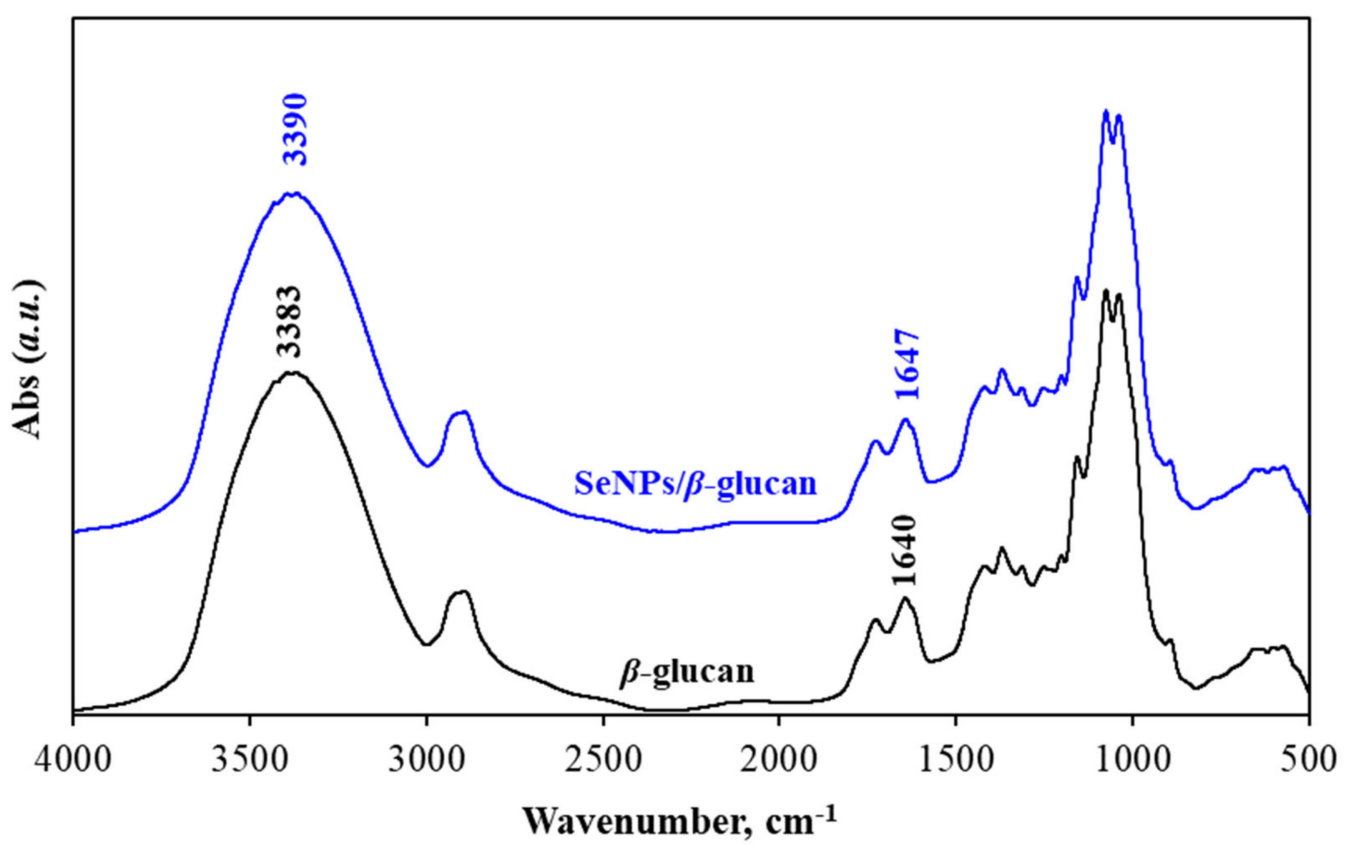

Figure 6. FTIR spectra of $\beta$-glucan and SeNPs / $\beta$-glucan synthesized by gamma irradiation at dose of $8 \mathrm{kGy}$ and dose rate of $10 \mathrm{kG} \mathrm{h}^{-1}$.

The crystal structure of SeNPs after irradiation was also confirmed by X-ray diffraction (XRD) analysis. The typical XRD pattern in Figure 7 indicated that SeNPs exhibited diffraction peaks at $23.7^{\circ}(100), 29.5^{\circ}(101), 42.7^{\circ}(110), 44.8^{\circ}(102), 46.2^{\circ}(111), 51^{\circ}$ (201) and $65.3^{\circ}$ (210) attributed to the crystal structure of SeNPs and these results are in good agreement with those reported in previous papers $[15,16,40,41]$. Based on the above results, we can conclude that a high purity and stable SeNPs / $\beta$-glucan was successfully synthesized by irradiation, and the capped mechanism illustrated in Figure 8 can be proposed.

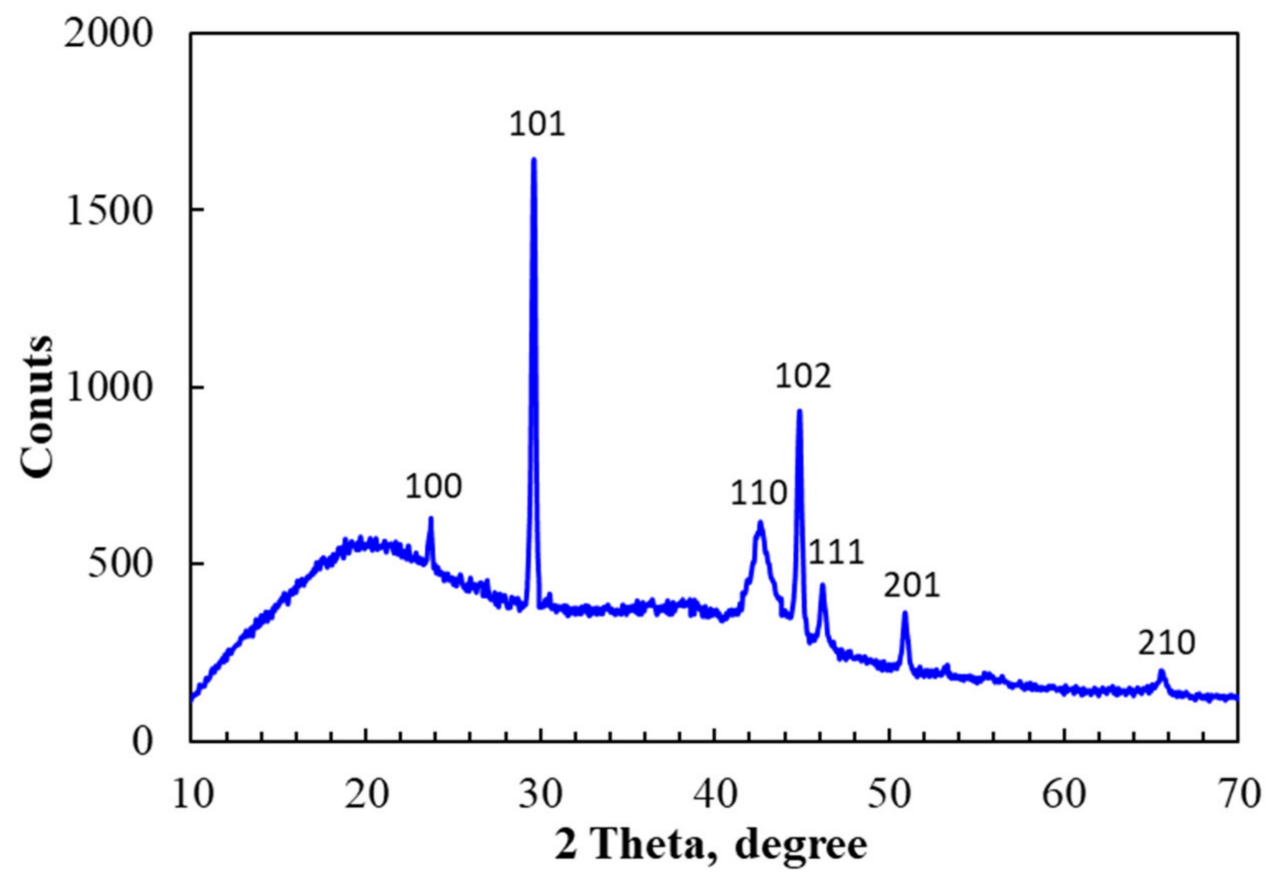

Figure 7. XRD pattern of SeNPs / $\beta$-glucan synthesized by gamma irradiation at a dose of $8 \mathrm{kGy}$ and dose rate of $10 \mathrm{kG} / \mathrm{h}$. 


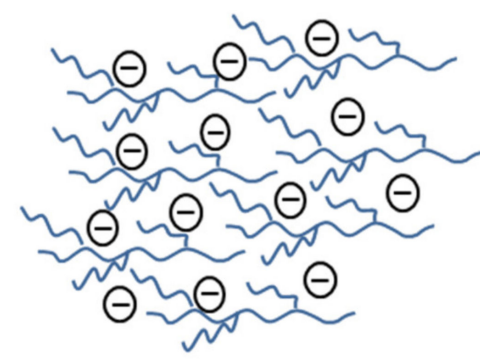

Mixture of

$\mathrm{SeO}_{3}{ }^{2-}$ and $\beta$-(1,3/1,6)-glucan

\section{Reducttion

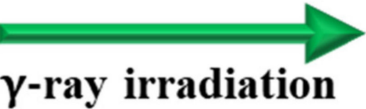

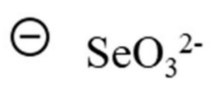

$\ominus \mathrm{SeO}_{3}^{2-}$

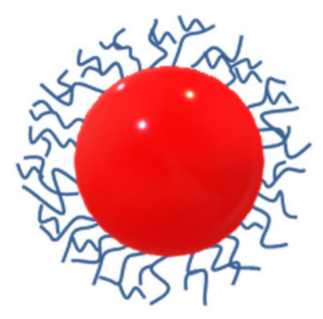

SeNPs/ $\beta$-Glucan

Figure 8. Schematic representation of the synthesis of SeNPs capped by $\beta$-glucan using gamma irradiation for reducing $\mathrm{Se}^{4+} \cdot 3.2$. Stability of the SeNP/ $\beta$-glucan solution by storage.

The stability of a colloidal nanoparticle solution is the most important for application and it depends on several factors including concentration, type of stabilizer, $\mathrm{pH}$ of solution and temperature during storage $[7,42]$. The properties of SeNPs/ $\beta$-glucan stored for 60 days at 0,4 and $25^{\circ} \mathrm{C}$ in this study are presented in Figure 9 . It can be clearly seen that the particle size of storage SeNPs / $\beta$-glucan slightly increased under $0{ }^{\circ} \mathrm{C}$ storage conditions, but these characteristics increased significantly in samples stored at $4{ }^{\circ} \mathrm{C}$ and increased strongly in samples kept at room temperature $\left(25^{\circ} \mathrm{C}\right)$. In addition, the particle size distribution was rather larger at higher storage temperature. Zeta potential is an important indicator of the stability of nanocolloidal suspensions. Figure $5 b$ indicates that the zeta potential of SeNPs / $\beta$-glucan was about $-6.9 \mathrm{mV}$ (approximately neutral); therefore, the temperature strongly affected the stability of this solution during storage. According to Bai et al. [25], nanoparticles are easily aggregated to form larger ones at high temperature due to Brownian movement. Duy et al. [16] also informed that the SeNP size in SeNPs/oligochitosan stored at $27{ }^{\circ} \mathrm{C}$ increased more rapidly than that at $4{ }^{\circ} \mathrm{C}$. The authors also reported that SeNPs/oligochitosan became unstable after storage for more than 28 days and turned into a black bulk mass after 42 days of storage at $25{ }^{\circ} \mathrm{C}$. Thus, it is challenging to maintain a colloidal SeNPs solution for a long time at normal temperature and the change of SeNPs solution into powder form is a suitable way for improving the applications of this product. Thao et al. [43] prepared AuNPs/dextran by spray drying, coagulation and centrifugation methods. These authors mentioned that the change of particle size in AuNPs powders prepared by the spray drying and coagulation techniques was less than that in AuNPs made by centrifugation. Recently, Duy et al. [16] reported that the particle size (estimated by TEM images) of SeNP/oligochitosan solution increased slightly from $41.8 \mathrm{~nm}$ to $43.8 \mathrm{~nm}$ in the powder form obtained after dry spraying. In the present study, the DLS analysis results (Figure 10) indicate that particle size and size distribution of SeNPs / $\beta$-glucan solution after changing to the powder form were increased. Particularly, the particle size of SeNPs / $\beta$-glucan increased slightly from $92 \mathrm{~nm}$ in the original solution to 95, 117.6 and $132.3 \mathrm{~nm}$ in powder products prepared by freeze drying method, coagulate and spray draying techniques, respectively. From the above results, the powder sample made from SeNPs / $\beta$-glucan solution contained 80 ppm $\mathrm{Se}^{4+}$ and $2 \% \beta$-glucan was selected for further evaluation of the immunostimulant activity in mice. 

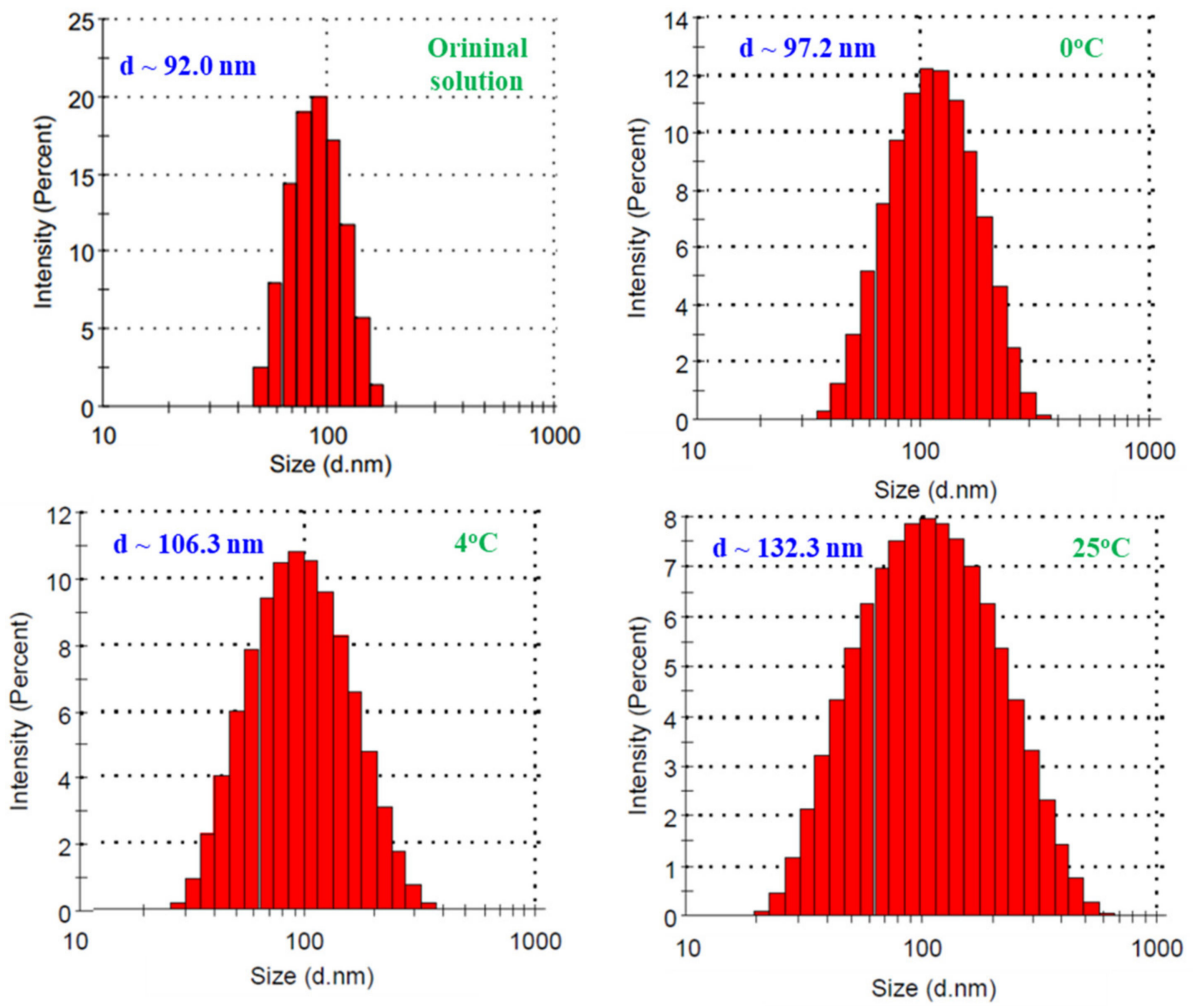

Figure 9. Particle size and size distribution of SeNPs / $\beta$-glucan solution after storage for 60 days at various temperatures.
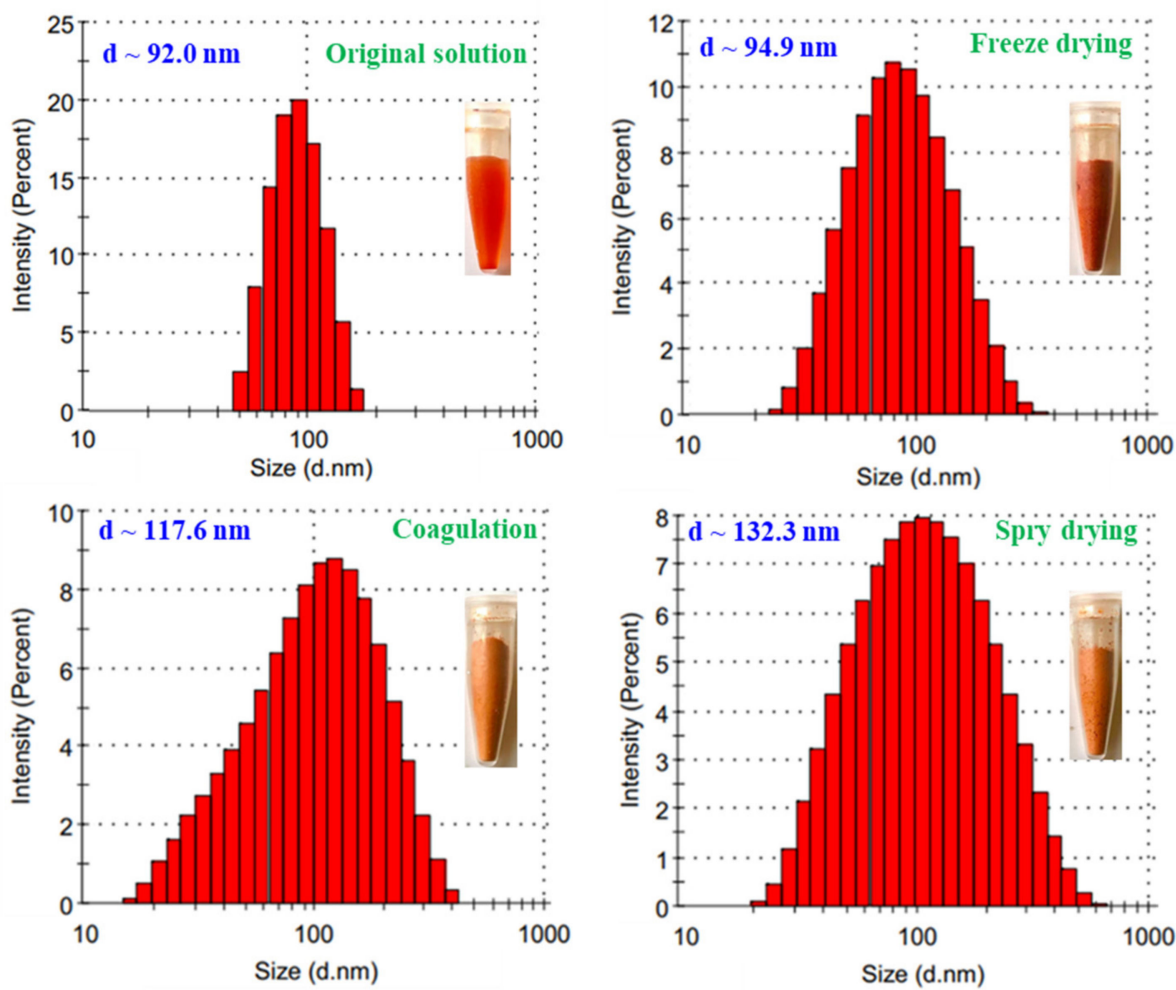

Figure 10. Particle size and size distribution of SeNPs / $\beta$-glucan solution and after changing into powder form by different techniques. 


\subsection{Effect of SeNPs/ $\beta$-Glucan on Immune Parameters in Peripheral Blood}

According to Ahlmann and Hempel [44], CTX is one of the most commonly used chemotherapy drug for various tumors, cancers and marrow transplantation. Therefore, a CTX-induced immunosuppressed mice model is usually used to evaluate the immunoregulatory activity of immunostimulant compounds [45]. In the present study, this chemical was used to induce immunosuppression in tested mice. It can be seen that all of immune indexes were strongly reduced in CTX-induced immunosuppressed mice and the oral administration of SeNPs / $\beta$-glucan displayed a strong ameliorating effect on these deficiencies.

In peripheral blood, white blood cells (WBCs) are a very important part of organisms' way of resisting external microorganisms and the differentiation in WBCs also affects the immune responses. The effects of SeNPs/ $\beta$-glucan supplied at various concentrations on cellular immune parameters in the peripheral blood of tested mice are displayed in Figure 11 and Figures S1-S6. It can be seen that the oral administration of SeNPs / $\beta$-glucan at a concentration of $2-6 \mathrm{mg} \mathrm{kg}^{-1}$ body weight enhanced WBCs in peripheral blood of CTX-induced immunosuppressed mice.
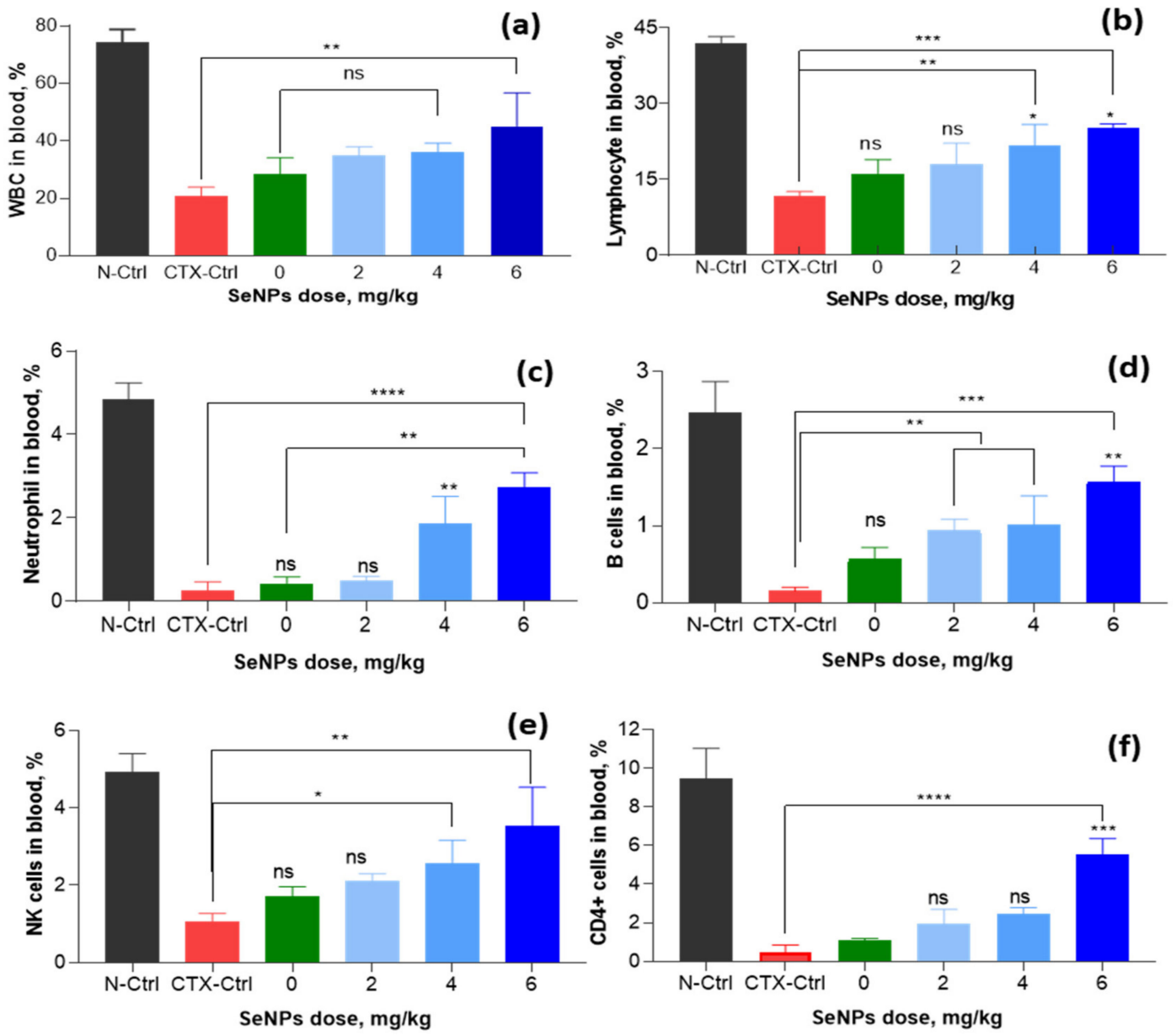

Figure 11. Effect of SeNPs/ $\beta$-glucan concentration on cellular immunity indexes in peripheral bloods of CTX-induced immunosuppressed mice. (a-f) are WBCs, lymphocytes, neutrophils, B cells, NK cells and CD4+ cells, respectively; N-Ctrl: Normal control mice received only distilled water; CTX-Ctrl: CTX-induced immunosuppressive mice received only distilled water; in supplemented groups, mice were orally supplied with 0 (only $\beta$-glucan without SeNPs), 2, 4 and 6 mg SeNPs kg ${ }^{-1}$. Significant differences were compared with the CTX-Ctrl. ns, not significantly different at $p>0.05$; ${ }^{*}$, significant different at $p<0.05 ;{ }^{* *}$, significant different at $p=0.01,{ }^{* * *}$ significant different at $p<0.01 ;{ }^{* * * *}$, significant different at $p<0.001$. Data were statistically analyzed using the ANOVA test and expressed as means $\pm \mathrm{SD}, n=3$. 
Compared to the content of WBC of peripheral blood in CTX-control mice (20.8\%), the supplementation of 4-6 mg kg-1 enhanced the contents of these immune cells to $35-45.1 \%$. In addition, the results on differentiated WBCs also showed that the ratio of neutrophils (from $0.27 \%$ to $1.87-2.73 \%$ ), lymphocytes (from $11.6 \%$ to $21.7-25.2 \%$ ), B cells (from $0.15 \%$ to $1.02-1.57 \%$ ) CD4+ cells (from $0.47 \%$ to $1.97-5.57 \%$ ) and NK cells (from $1.07 \%$ to $2.57-3.53 \%$ ) also significantly increased in peripheral blood of mice in group supplemented with 4-6 mg SeNPs/ $\beta$-glucan.

Generally, immune molecules including immunoglobulins are the main factors in the immune system of the body besides immune cells and organs. The results in Figure 12 also demonstrate that compared to IgG $\left(687.3 \mu \mathrm{g} \mathrm{mL}{ }^{-1}\right)$, IgM $\left(137.1 \mu \mathrm{g} \mathrm{mL}^{-1}\right)$, TNF- $\alpha$ $\left(35.5 \mu \mathrm{g} \mathrm{mL}^{-1}\right)$ and IFN- $\gamma\left(1.2 \mu \mathrm{g} \mathrm{mL}^{-1}\right)$ in the CTX-control group, the supplementations of 2-6 mg SeNPs kg ${ }^{-1}$ increased these levels to 243-285.7, 1491-1730.1, 54.6-62.4 and 1.6-2.11 $\mu \mathrm{g} \mathrm{mL}^{-1}$, respectively. The highest levels of these indexes were found in the group fed with $6 \mathrm{mg}$ SeNPs kg $^{-1}$ and were almost the same as those of normal control animals.
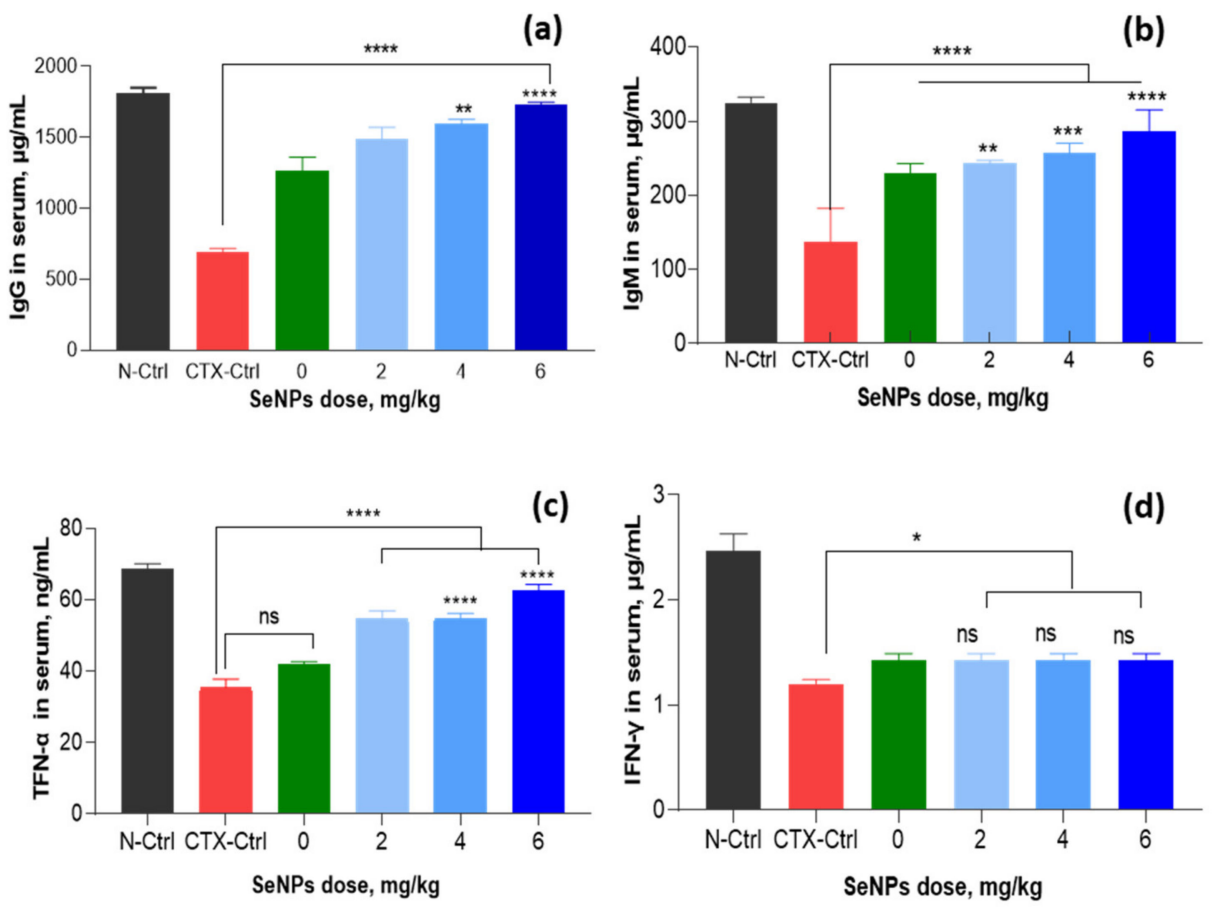

Figure 12. Effect of SeNPs / $\beta$-glucan concentration on humoral immunity factors in serum of CTXinduced immunosuppressed mice. (a-d) are IgG, IgM, TFN- $\alpha$ and IFN- $\gamma$ indexes, respectively; N-Ctrl: Normal control mice received only distilled water; CTX-Ctrl: CTX-induced immunosuppressive mice received only distilled water; in supplemented groups, mice were orally supplied with 0 (only $\beta$-glucan without SeNPs), 2, 4 and $6 \mathrm{mg} \mathrm{SeNPs} \mathrm{kg}^{-1}$. Significant differences were compared with the CTX-Ctrl. ns, not significantly different at $p>0.05 ;{ }^{*}$, significant different at $p<0.05 ;{ }^{* *}$, significant different at $p=0.01,{ }^{* * *}$ significant different at $p<0.01 ;{ }^{* * *}$, significant different at $p<0.001$. Data were statistically analyzed using the ANOVA test and expressed as means $\pm \mathrm{SD}, n=3$.

Although the ameliorating effect of SeNPs on chemical-induced immunosuppression in mice has not been reported, Menon et al. [17] and Gao et al. [46] have indicated that SeNPs capped by glutathione and BSA with particle size about $22.7 \mathrm{~nm}$ could enhance the chemotherapeutic activity by acting as a functional division of redox center and protecting tissues from cellular damage caused by ROS. Shakibaie et al. [47] indicated that the total number of WBCs in normal mice was significantly increased by feeding with SeNPs suspended in deionized water with particle size in range of $80-220 \mathrm{~nm}$ at a concentration of $20 \mathrm{mg} \mathrm{kg}^{-1}$. SeNPs was also reported to restore WBCs in radiation-induced immunosuppressed mice. Yazdi et al. [48] also demonstrated that the daily administration of biogenic 
SeNPs suspended in deionized water with particle size in range of $80-220 \mathrm{~nm}$ at a dose of $100 \mu \mathrm{g}$ per mouse led to an increase in the WBCs including total number of neutrophil and lymphocyte cells in blood of X-ray irradiated mice. Duy el at. [16] have reported that the daily administration of $20 \mu \mathrm{g}$ SeNPs/oligochitosan with particle size about $43.8 \mathrm{~nm}$ synthesized by $\gamma$-irradiation also showed a strong effect on WBC recovery in the blood of $\gamma$-ray irradiated mice. Recently, Raahati et al. [49] also demonstrated that the oral supplementation of SeNPs capped by Tween 20 with particle size about $48 \mathrm{~nm}$ at a dose of $100 \mu \mathrm{g}$ per head led to a significant increase of $V$. cholera-specific immunoglobulins (IgG and IgA) and interleukin (IL-4 and IL-5) responses in the serum of mice challenged with $V$. cholera bacteria. The above information indicates that the immunostimulant activity of SeNPs seems to be not affected by capping polymers. It can be seen clearly from Figures 11 and 12 that both cellular immune factors (WBCs, neutrophil, lymphocyte, B cells, CD4+ cells and NK cells) and humoral immune indexes (IgG, IgM, TNF- $\alpha$ and IFN- $\gamma$ ) in peripheral blood CTX-control and the $\beta$-glucan treated mice were not significantly different. Although $\beta$-glucan did not show a significant effect on the immunostimulation in CTX-induced immunosuppressed mice, this natural polymer has been widely applied in the food and pharmaceutical industries due to its excellent biocompatibility [27-29]. In addition, Zhang et al. [50] also demonstrated that SeNPs with particle sizes ranging from 5 to $200 \mathrm{~nm}$ did not show a size-dependent effect in upregulating seleno-enzymes, both in cultured cells and mice. The results in the present research reveal that the SeNPs / $\beta$-glucan prepared by $\gamma$-irradiation significantly ameliorated the differentiated WBCs, level of immunoglobulins (IgG and IgM) and cytokines (TNF- $\alpha$ and IFN- $\gamma$ ) in peripheral blood of CTX-induced immunosuppressed mice.

\subsection{Effect of SeNPs/B-Glucan on Immune Parameters in Bone Marrow}

In mammals and humans, bone marrow is a hematopoietic organ and central immune organ of humans and mammals and bone marrow suppression is one of the most obvious side effects of drug chemotherapy, including CTX treatment $[36,44]$. It was reported that the lifetime of WBCs in peripheral blood is short and they need to be continuously complemented from bone marrow [51]. So far, the effect of SeNPs on cell differentiation or cytokine levels of bone marrow suspension in mice immunosuppressed by chemicals has not been reported. Therefore, effect of SeNPs / $\beta$-glucan on cytokines of bone marrow suspension of CTX-treated mice was evaluated in this study. The analysis results in bone marrow of tested mice from our investigation indicated that the ratio of WBC was significantly increased in bone marrow suspensions of mice in all groups administrated with SeNPs / $\beta$-glucan compared to the CTX-control group supplied with only distilled water (Figure 13 and Figures S7-S9). Particularly, the WBC ratio in bone marrow suspension of the CTX-control group was determined at $11.2 \%$ and these ratios in groups fed with 2,4 and $6 \mathrm{mg} \mathrm{SeNPs} / \beta$-glucan were significantly increased to $52.3,75.5$ and $84.6 \%$, respectively. On the other hand, the oral supplementation with $6 \mathrm{mg}$ SeNPs product also led to the strongest effects on the increase of lymphocytes (44.4\%) and CD34+ cells (3.6\%) in tested mice. The increasing proliferation of immune cells in bone marrow suspension could activate the immune system and modulate the immune activity in immunosuppressed mice. These results also revealed clearly that SeNPs/ $\beta$-glucan prepared by $\gamma$-irradiation significantly ameliorated immune cell proliferation in bone marrow, which is very important for a continuously maintenance at a high level of cellular and humoral immune factors in the peripheral blood of immunosuppressed mice. The suitable concentration for oral administration of this product was determined to be about $4-6 \mathrm{mg} \mathrm{kg}^{-1}$. 

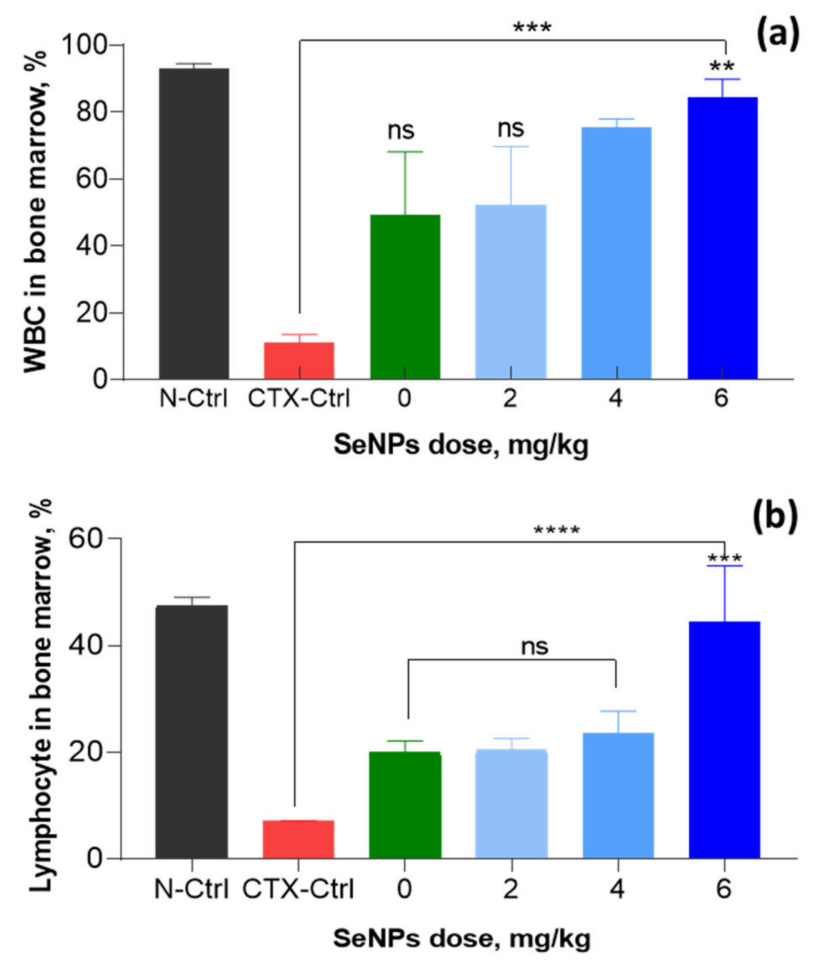

(b)

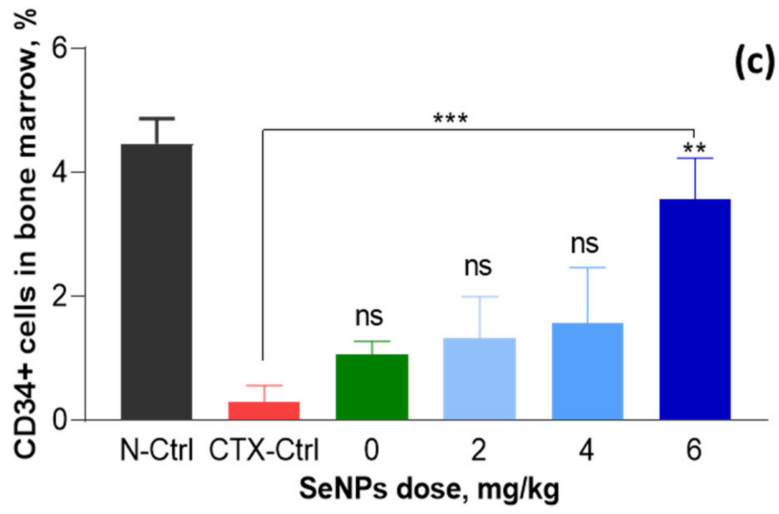

Figure 13. Effect of SeNPs / $\beta$-glucan concentration on cellular immunity indexes in bone marrow of CTX-induced immunosuppressed mice. $(\mathbf{a}-\mathbf{c})$ are WBCs, lymphocytes and CD34+ cells, respectively; N-Ctrl: Normal control mice received only distilled water; CTX-Ctrl: CTX-induced immunosuppressed mice received only distilled water; in supplemented groups, mice were orally supplied with 0 (only $\beta$-glucan without SeNPs), 2, 4 and $6 \mathrm{mg} \mathrm{SeNPs} \mathrm{kg}^{-1}$. Significant differences were compared with the CTX-Ctrl. ns, not significantly different at $\mathrm{p}>0.05 ; * *$, significant different at $p=0.01$, *** significant different at $p<0.01 ;{ }^{* * *}$, significant different at $p<0.001$. Data were statistically analyzed using the ANOVA test and expressed as means $\pm \mathrm{SD}, n=3$.

\subsection{Effect of SeNPs/ $\beta$-Glucan on Immune Parameters in Spleen}

Beside bone marrow, the spleen is also an important immune organ due to its close relation to cellular immunity and humoral immunity. Raahati et al. [49] and Yazdi et al. [13] have reported that biogenic SeNPs with a concentration of $100 \mu \mathrm{g}$ per day significantly enhanced the levels of cellular immunomodulatory components (granzyme B, IL-12, IFN- $\gamma$, and IL-2) in the spleen cells of tumor-bearing mice. The results in Figure 14 indicate that the spleen index of CTX-control group mice was $16.3 \mathrm{mg} 10 \mathrm{~g}^{-1}$ and this value was increased in to $21.5-37.3 \mathrm{mg} 10 \mathrm{~g}^{-1}$ in groups fed with SeNPs / $\beta$-glucan at concentrations of 2-6 mg kg $\mathrm{m}^{-1}$, respectively. In addition, Figure 14 also shows that the levels of IgM, IgG, TNF$\alpha$, IFN- $\gamma$ and IL-2 in the CTX-control group were found to be about 5.0, 8.7, 23.4, 1.2 and $0.78 \mu \mathrm{g} \mathrm{mL}^{-1}$, respectively. These levels were much lower than those in the normal control 
group and they were strongly recovered in groups supplemented with SeNPs/ $\beta$-glucan. Particularly, the supplementation with $2-6 \mathrm{mg} \mathrm{kg}^{-1}$ SeNPs/ $\beta$-glucan increased IgM, IgG, TNF- $\alpha$, IFN- $\gamma$ and IL-2 levels to $12.2-17.3,28.2-37.8,56.2-97.2,2.0-2.9$ and $2.7-4.6 \mu \mathrm{g} \mathrm{mL}{ }^{-1}$, respectively. The highest levels of these indexes were found in the group of mice fed with $6 \mathrm{mg} \mathrm{kg}^{-1}$, being almost the same as those of the normal control animals.

(a)
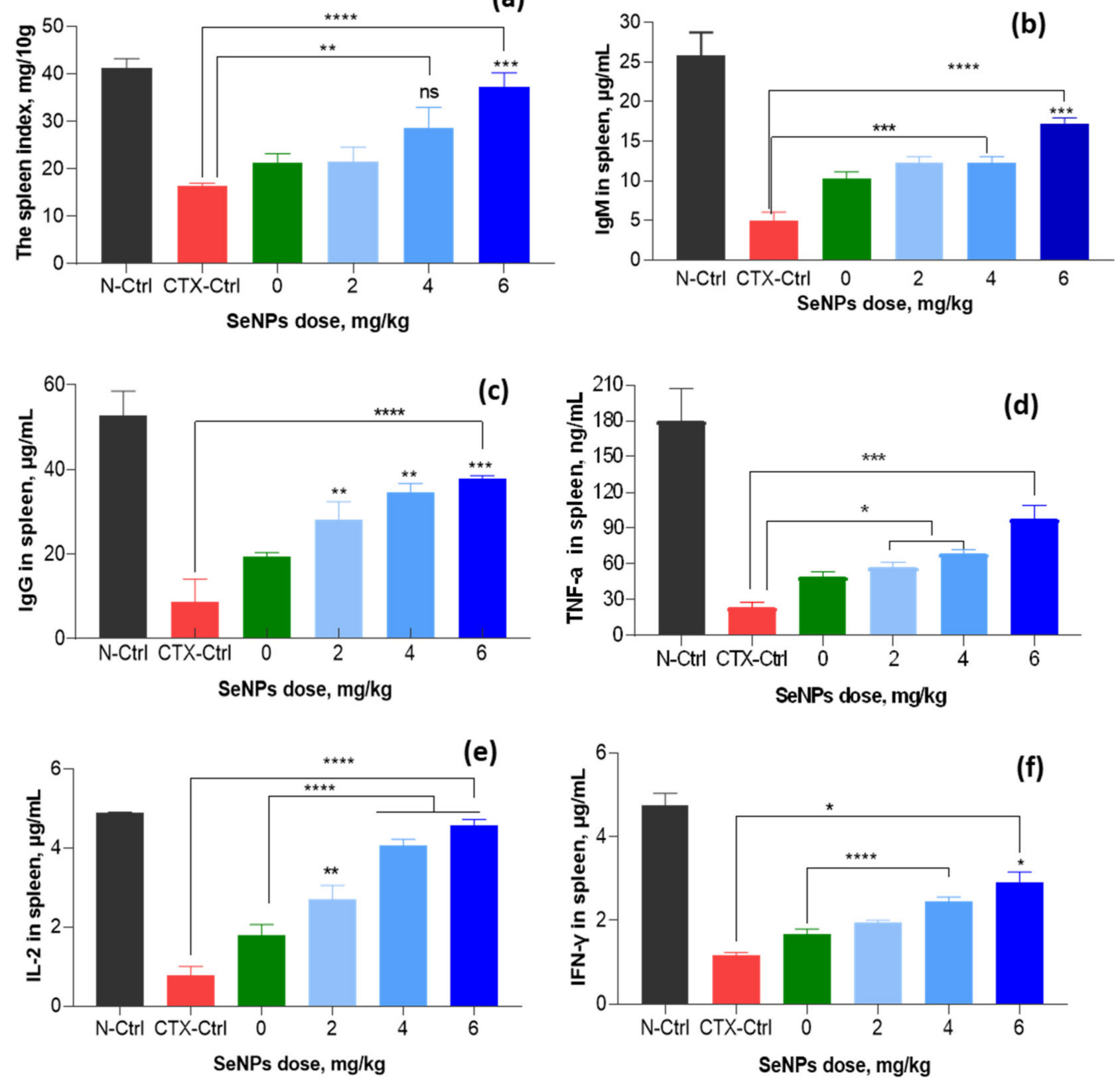

Figure 14. Effect of SeNPs / $\beta$-glucan concentration on immunity factors in spleen of immunosuppressed mice. (a-f) are spleen, IgM, IgG, TFN- $\alpha$, IL-2 and IFN- $\gamma$ indexes, respectively; N-Ctrl: Normal control mice received only distilled water; CTX-Ctrl: CTX-induced immunosuppressive mice received only distilled water; in supplemented groups, mice were orally supplied with 0 (only $\beta$-glucan without SeNPs), 2, 4 and $6 \mathrm{mg} \mathrm{SeNPs} \mathrm{kg}{ }^{-1}$. Significant differences were compared with the CTX-Ctrl. ns, not significantly different at $p>0.05$; ${ }^{*}$, significant different at $p<0.05 ;{ }^{* *}$, significant different at $p=0.01$, ${ }^{* * *}$ significant different at $p<0.01 ;{ }^{* * *}$, significant different at $p<0.001$. Data were statistically analyzed using the ANOVA test and expressed as means $\pm \mathrm{SD}, n=3$. 
The above results in the tested mice clearly reveal that the oral administration of SeNPs / $\beta$-glucan synthesized by $\gamma$-ray irradiation at a daily dose of $6 \mathrm{mg} \mathrm{kg}^{-1}$ significantly ameliorated the immune system suppression caused by CXT treatment in mice.

\section{Conclusions}

SeNPs with diameter from 64.8 to $110.1 \mathrm{~nm}$ capped by water soluble $\beta$-glucan were synthesized by gamma Co-60 ray irradiation. The daily supplementation of radiationsynthesized SeNPs / $\beta$-glucan at $6 \mathrm{mg} \mathrm{kg}^{-1}$ strongly restored the cellular immune factors (WBC, neutrophils, monocytes, lymphocytes, B cells and NK cells) and humoral immune indexes (IgM, IgG, TNF- $\alpha$, IFN- $\gamma$ and IL-2) in peripheral blood, bone marrow and spleen of CTX-induced immunosuppressed mice. Due to the excellent biocompatibility of $\beta$-glucan, as well as the unique attributes of SeNPs, the SeNPs / $\beta$-glucan product may be a candidate for application as a functional food for the prevention of immunosuppression in cancer chemotherapy. The in vivo release in blood and biodistribution of SeNPs will be further evaluated to elucidate the pathway of its action.

Supplementary Materials: The following are available online at https:/ /www.mdpi.com/article/10 $.3390 /$ nano11092439/s1, Figure S1. The typical flow cytometry scatter plots of WBCs in peripheral bloods of normal control mice received only distilled water (N-Ctrl), CTX-induced immunosuppressive mice received only distilled water (CTX-Ctrl) and mice supplied with $6 \mathrm{mg} \mathrm{SeNPs} \mathrm{kg}{ }^{-1}$ for 14 days; Figure S2. The typical flow cytometry scatter plots of lymphocyte in peripheral bloods of normal control mice received only distilled water (N-Ctrl), CTX-induced immunosuppressive mice received only distilled water (CTX-Ctrl) and mice supplied with $6 \mathrm{mg} \mathrm{SeNPs} \mathrm{kg}^{-1}$ for 14 days; Figure S3. The typical flow cytometry scatter plots of neutrophil in peripheral bloods of normal control mice received only distilled water (N-Ctrl), CTX-induced immunosuppressive mice received only distilled water (CTX-Ctrl) and mice supplied with $6 \mathrm{mg} \mathrm{SeNPs} \mathrm{kg}^{-1}$ for 14 days; Figure S4. The typical flow cytometry scatter plots of B cells in peripheral bloods of normal control mice received only distilled water (N-Ctrl), CTX-induced immunosuppressive mice received only distilled water (CTX-Ctrl) and mice supplied with $6 \mathrm{mg} \mathrm{SeNPs} \mathrm{kg}^{-1}$ for 14 days; Figure S5. The typical flow cytometry scatter plots of natural killer cells in peripheral bloods of normal control mice received only distilled water (N-Ctrl), CTX-induced immunosuppressive mice received only distilled water (CTX-Ctrl) and mice supplied with $6 \mathrm{mg} \mathrm{SeNPs} \mathrm{kg}^{-1}$ for 14 days; Figure S6. The typical flow cytometry scatter plots of CD4+ cells in peripheral bloods of normal control mice received only distilled water (N-Ctrl), CTX-induced immunosuppressive mice received only distilled water (CTX-Ctrl) and mice supplied with $6 \mathrm{mg}$ SeNPs $\mathrm{kg}^{-1}$ for 14 days; Figure S7. The typical flow cytometry scatter plots of WBCs in bone marrow of normal control mice received only distilled water (N-Ctrl), CTX-induced immunosuppressive mice received only distilled water (CTX-Ctrl) and mice supplied with $6 \mathrm{mg}$ SeNPs $\mathrm{kg}^{-1}$ for 14 days; Figure S8. The typical flow cytometry scatter plots of lymphocytes in bone marrow of normal control mice received only distilled water (N-Ctrl), CTX-induced immunosuppressive mice received only distilled water (CTX-Ctrl) and mice supplied with $6 \mathrm{mg} \mathrm{SeNPs} \mathrm{kg}^{-1}$ for 14 days; Figure S9. The typical flow cytometry scatter plots of CD34+ cells in bone marrow of normal control mice received only distilled water (N-Ctrl), CTX-induced immunosuppressive mice received only distilled water (CTX-Ctrl) and mice supplied with $6 \mathrm{mg} \mathrm{SeNPs} \mathrm{kg}^{-1}$ for 14 days.

Author Contributions: Funding acquisition, L.Q.L.; Project administration, L.Q.L.; Resource, N.T.V., N.T.D.; Conceptualization, N.T.D., L.Q.L. and T.T.L.M.; Methodology, N.T.D., L.Q.L. and N.T.B.; Validation, L.Q.L. and T.T.L.M.; Software, N.T.D., N.T.V., T.D.T.; Formal analysis N.T.D., L.Q.L., T.D.T. and N.T.B.; Investigation, N.T.D., N.T.B., N.T.V., T.D.T. and L.Q.L.; Data curation, N.T.D., L.Q.L., N.T.V. and T.D.T.; Writing-original draft preparation, N.T.D. and T.D.T.; Writing-review and editing, L.Q.L. and T.T.L.M. All authors have read and agreed to the published version of the manuscript.

Funding: This research was supported by Science and Technology Department of Ho Chi Minh City (Project No. 100/2019/HĐ-QPTKHCN) and Biotechnology Center of Ho Chi Minh City.

Institutional Review Board Statement: The study was conducted according to the guidelines for animal research of (AAALAC) and approved by the Institutional Review Board of the Scientific Council of the Biotechnology Center of Ho Chi Minh City (approval No.: 380/QĐ-CNSH). 
Data Availability Statement: The data presented in this study are available on a reasonable request from the corresponding author.

Conflicts of Interest: The authors declare that they have no conflict of interest regarding the publication of this article.

$\begin{array}{ll}\text { Abbreviations } \\ \text { ANOVA } & \text { Analysis of variance } \\ \text { BSA } & \text { bovine serum albumin } \\ \text { CTX } & \text { cytoxan } \\ \text { DLS } & \text { dynamic light scattering } \\ \text { FBS } & \text { fetal bovine serum } \\ \text { FTIR } & \text { Fourier transform infrared spectroscopy } \\ \text { IL-2 } & \text { interleukin } 2 \\ \text { IFN- } \gamma & \text { interferon- } \gamma \\ \text { IgG } & \text { immunoglobulin G } \\ \text { IgM } & \text { immunoglobulin M } \\ \text { LSD } & \text { least significant difference } \\ \text { NK cell } & \text { natural killer cell } \\ \text { PBS } & \text { phosphate buffered saline } \\ \text { SeNPs } & \text { selenium nanoparticles } \\ \text { TEM } & \text { transmission electron microscopy } \\ \text { TNF- } \alpha & \text { tumor necrosis factor alpha } \\ \text { WBC } & \text { white blood cell } \\ \text { XRD } & \text { X-ray diffraction }\end{array}$

\section{References}

1. Beck, M.A.; Levander, O.A.; Handy, J. Selenium deficiency and viral infection. J. Nutr. 2003, 133, 1463S-1467S. [CrossRef]

2. Hoffmann, P.R.; Berry, M.J. The influence of selenium on immune responses. Mol. Nutr. Food Res. 2008, 52, 1273-1280. [CrossRef]

3. Zeng, H.; Combs, G.F.J. Selenium as an anticancer nutrient: roles in cell proliferation and tumor cell invasion. J. Nutr. Biochem. 2008, 19, 1-7. [CrossRef]

4. Lin, Z.-H.; Wang, C.R.C. Evidence on the size-dependent absorption spectral evolution of selenium nanoparticles. Mater. Chem. Phys. 2005, 92, 591-594. [CrossRef]

5. Yang, L.B.; Shen, Y.H.; Xie, A.J.; Liang, J.J.; Zhang, B.C. Synthesis of Se nanoparticles by using TSA ion and its photocatalytic application for decolorization of cango red under UV irradiation. Mater. Res. Bull. 2008, 43, 572-582. [CrossRef]

6. Raevskaya, A.E.; Stroyuk, A.L.; Kuchmiy, S.Y.; Dzhagan, V.M.; Zahn, D.R.T.; Schulze, S. Annealing-induced structural transformation of gelatin-capped Se nanoparticles. Solid State Commun. 2008, 145, 288-292. [CrossRef]

7. Hien, N.Q.; Tuan, P.D.; Van Phu, D.; Lan, N.T.K.; Duy, N.N.; Hoa, T.T. Gamma Co-60 ray irradiation synthesis of dextran stabilized selenium nanoparticles and their antioxidant activity. Mater. Chem. Phys. 2018, 205, 29-34. [CrossRef]

8. Zhang, J.; Wang, H.; Yan, X.; Zhang, L. Comparison of short-term toxicity between nano-Se and selenite in mice. Life Sci. 2005, 76, 1099-1109. [CrossRef] [PubMed]

9. Pelyhe, C.; Mezes, M. Myths and facts about the effects of nano-selenium in farm animals- mini review. Eur. Chem. Bull. 2013, 2, 1049-1052.

10. Zhang, J.; Wang, X.; Xu, T. Elemental selenium at nano size (Nano-Se) as a potential chemopreventive agent with reduced risk of selenium toxicity: comparison with se-methylselenocysteine in mice. Toxicol. Sci. 2008, 101, 22-31. [CrossRef]

11. Zhai, X.; Zhang, C.; Zhao, S.; Stoll, S.; Ren, F.; Leng, X. Antioxidant capacities of the selenium nanoparticles stabilized by chitosan. J. Nanobiotechnol. 2017, 15, 4. [CrossRef]

12. Hosnedlova, B.; Kepinska, M.; Skalickova, S.; Fernandez, C.; Ruttkay-Nedecky, B.; Peng, Q.; Baron, M.; Melcova, M.; Opatrilova, R.; Zidkova, J.; et al. Nano-selenium and its nanomedicine applications: A critical review. Int. J. Nanomed. 2018, 13, $2107-2128$. [CrossRef] [PubMed]

13. Yazdi, M.H.; Mahdavi, M.; Varastehmoradi, B.; Faramarzi, M.A.; Shahverdi, A.R. The immunostimulatory effect of biogenic selenium nanoparticles on the 4T1 breast cancer model: an in vivo study. Biol. Trace. Elem. Res. 2012, 149, 22-28. [CrossRef]

14. Yazdi, M.H.; Mahdavi, M.; Faghfuri, E.; Faramarzi, M.A.; Sepehrizadeh, Z.; Hassan, Z.M.; Gholami, M.; Shahverdi, A.R. Th1 immune response induction by biogenic selenium nanoparticles in mice with breast cancer: preliminary vaccine model. Iran $J$. Biotechnol. 2015, 13, 1-9. [CrossRef] [PubMed]

15. Jia, X.; Liu, Q.; Zou, S.; Xu, X.; Zhang, L. Construction of selenium nanoparticles/ $\beta$-glucan composites for enhancement of the antitumor activity. Carbohydr. Polym. 2015, 117, 434-442. [CrossRef] 
16. Duy, N.N.; Phu, D.V.; Quoc, L.A.; Lan, N.T.K.; Hien, N.Q.; Ngan, T.T.T.; Ha, T.L.B.; Tuan, P.D.; Ha, B.M. Preparation and effect of selenium nanoparticles/oligochitosan on the white blood cell recovery of mice exposed to gamma-ray radiation. J. Chem. 2021, $2021,6635022$.

17. Menon, S.; Ks, S.D.; Santhiya, R.; Rajeshkumar, S.; Kumar, V. Selenium nanoparticles: A potent chemotherapeutic agent and an elucidation of its mechanism. Colloids Surf. B Biointerfaces 2018, 170, 280-292. [CrossRef]

18. Kumari, M.; Ray, L.; Purohit, M.P.; Patnaik, S.; Pant, A.B.; Shukla, Y.; Kumar, P.; Gupta, K.C. Curcumin loading potentiates the chemotherapeutic efficacy of selenium nanoparticles in HCT116 cells and Ehrlich's ascites carcinoma bearing mice. Eur. J. Pharm. Biopharm. 2017, 117, 346-362. [CrossRef]

19. Wang, Y.; Chen, P.G.; Zhao, K.; Sun, D.; Li, X.; Wan, J. Inverse relationship between elemental selenium nanoparticle size and inhibition of cancer cell growth in vitro and in vivo. Food Chem. Toxicol. 2015, 85, 71-77. [CrossRef] [PubMed]

20. Peng, D.; Zhang, J.S.; Liu, Q.L.; Ethan, W.T. Size effect of elemental selenium nanoparticles (Nano-Se) at supranutritional levels on selenium accumulation and glutathione S-transferase activity. J. Inorg. Biochem. 2007, 101, 1457-1463. [CrossRef] [PubMed]

21. Huang, B.; Zhang, J.; Hou, J.; Chen, C. Free radical scavenging efficiency of Nano-Se in vitro. Free Radical Biol. Med. 2003, 35, 805-813. [CrossRef]

22. Zhou, Y.M.; Xu, Y.L.; Bai, Y.; Deng, Y.; Liu, J.; Chen, L. Green synthesis of Se/Ru alloy nanoparticles using gallic acid and evaluation of theiranti-invasive effects in HeLa cells. Colloids Surf. B Biointerfaces 2016, 144, 118-124. [CrossRef]

23. Liu, T.; Zeng, L.; Jiang, W.; Fu, Y.; Zheng, W.; Chen, T. Rational design of cancertargeted selenium nanoparticles to antagonize multidrug resistance in cancer cells. Nanomed. Nanotechnol. Biol. Med. 2015, 11, 947-958. [CrossRef] [PubMed]

24. Yang, F.; Tang, Q.; Zhong, X.; Bai, Y.; Zhang, Y.; Zheng, W. Surface decoration by Spirulina polysaccharide enhances the cellular uptake and anticancer efficacy of selenium nanoparticles. Int. J. Nanomed. 2012, 7, 835-844.

25. Bai, K.; Hong, B.; He, J.; Hong, Z.; Tan, R. Preparation and antioxidant properties of selenium nanoparticles-loaded chitosan microspheres. Int. J. Nanomed. 2017, 12, 4527-4539. [CrossRef]

26. Zhang, C.; Zhai, X.; Zhao, G.; Ren, F.; Leng, X. Synthesis, characterization, and controlled release of selenium nanoparticles stabilized by chitosan of different molecular weights. Carbohydr. Polym. 2015, 134, 158-166. [CrossRef] [PubMed]

27. Zechner-krpan, V.; Petravić-tominac, V.; Panjkota-krbavčić, I.; Grba, S.; Berković, K. Potential application of yeast $\beta$-Glucans in food industry. Agric. Conspec. Sci. 2009, 74, 277-282.

28. Suzuki, T.; Tanaka, H.; Kinoshita, A.; Oikawa, S.; Osawa, M.; Yadomae, T. Effect of orally administered beta-glucan in macrophage function in mice. Int. J. Immunopharmacol. 1990, 12, 675-684. [CrossRef]

29. Reed, G.; Nagodawithana, T.W. Yeast-derived products and food and feed yeast. In Yeast Technology; Van Nostrand Reinhold: New York, NY, USA, 1991.

30. Sung, N.Y.; Byun, E.H.; Kwon, S.K.; Song, B.S.; Choi, J.I.; Kim, J.H.; Byun, M.W.; Yoo, Y.C.; Kim, M.R.; Lee, J.W. Immune enhancing activities of low molecular weight $\beta$-glucan depolymerized by gamma irradiation. Rad. Phys. Chem. 2009, 78, 433-436. [CrossRef]

31. Sung, N.Y.; Choi, J.; Yoon, Y.; Lee, S.Y.; Byun, M.W.; Hwang, Y.J.; Koenari, Z.I.; Lee, J.W.; Kim, J.H. Anti-allergic Effect of Low Molecular Weight $\beta$-Glucan Prepared by $\gamma$-Irradiation. Food Sci. Biotechnol. 2011, 20, 841-844. [CrossRef]

32. Lee, J.W.; Byun, E.H.; Sung, N.Y.; Raghavendran, H.R.B.; Byun, E.B.; Kim, J.H.; Choi, J.; Shin, M.G.; Byun, M.W. Effect of gamma irradiation on the efficacy of $\beta$-glucan against acetaminophen induced toxicity in mice. Chem. Biol. Interact. 2009, 180, 98-105. [CrossRef]

33. Long, N.T.; Anh, N.; Giang, B.L.; Son, H.N.; Luan, L.Q. Radiation Degradation of $\beta$-Glucan with a Potential for Reduction of Lipids and Glucose in the Blood of Mice. Polymers 2019, 11, 955. [CrossRef]

34. Mathew, M.; Nayarana, B. An easy spectrophotometric determination of selenium using azure B as a chromogenic reagent. Indian J. Chem. Technol. 2006, 13, 155-158.

35. Guo, M.Z.; Meng, M.; Feng, C.C.; Wang, X.; Wang, C.L. A novel polysaccharide obtained from Craterellus cornucopioides enhances immunomodulatory activity in immunosuppressive mice models via regulation of the TLR4-NF-kB pathway. Food Funct. 2019, 10, 4792-4801. [CrossRef]

36. Han, L.; Meng, M.; Guo, M.; Cheng, D.; Shi, L.; Wang, X.; Wang, C. Immunomodulatory activity of a water-soluble polysaccharide obtained from highland barley on immunosuppressive mice models. Food Funct. 2018, 10, 304-314. [CrossRef]

37. Hien, N.Q.; Phu, D.V.; Duy, N.N.; Quoc, L.A. Radiation synthesis and characterization of hyaluronan capped gold nanoparticles. Carbohydr. Polym. 2012, 89, 537-541. [CrossRef] [PubMed]

38. Khoa, N.D.; Christelle, K.; Laurent, D.; Xavier, C.; Hien, N.Q. Radiation synthesis of chitosan stabilized gold nanoparticles comparison between e- beam and $\gamma$ irradiation. Rad. Phys. Chem. 2014, 94, 84-87.

39. Souza, T.G.F.; Ciminelli, V.S.T.; Mohallem, N.D.S. A comparison of TEM and DLS methods to characterize size distribution of ceramic nanoparticles. J. Phys. 2016, 733, 012039. [CrossRef]

40. Miguel, A.; Ruiz, F.; Jsemaría, D.M.; Jaime, G.B.; María, V.F.C.; Germán, B.E.; Marcos, F.M.M.; Mohamed, L.M. Green synthesis and biotransformation of amorphous Se nanospheres to trigonal 1D Se nanostructures: impact on Se mobility within the concept of radioactive waste disposal. Environ. Sci. Nano 2018, 5, 2103-2116.

41. Menazeaa, A.A.; Ismail, A.M.; Nasser, S.A.; Hala, A.I. Physical characterization and antibacterial activity of VA/Chitosan matrix doped by selenium nanoparticles prepared via one-pot laser ablation route. J. Mater. Res. Technol. 2020, 9, 9598-9606. [CrossRef]

42. Piacenza, E.; Presentato, A.; Ferrante, F.; Cavallaro, G.; Alduina, R.; Martino, D.F.C. Biogenic Selenium Nanoparticles: A Fine Characterization to Unveil Their Thermodynamic Stability. Nanomaterials 2021, 11, 1195. [CrossRef] 
43. Thao, D.T.T.; Phu, D.V.; Duy, N.N.; Quy, H.T.D.; Hoa, T.T.; Hien, N.Q. Synthesis of gold nanoparticles stabilized in dextran solution by gamma Co-60 ray irradiation and preparation of gold nanoparticles/dextran powder. J. Chem. 2017, 2017, 1-8.

44. Ahlmann, M.; Hempel, G. The effect of cyclophosphamide on the immune system: implications for clinical cancer therapy. Cancer Chemother. Pharmacol. 2016, 78, 661-671. [CrossRef]

45. Zhang, W.N.; Gong, L.L.; Liu, Y.; Zhou, Z.B.; Wan, C.X.; Xu, J.J.; Chen, Y. Immunoenhancement effect of crude polysaccharides of Helvella leucopus on cyclophosphamide-induced immunosuppressive mice. J. Funct. Foods 2020, 69, 103942. [CrossRef]

46. Gao, F.; Yuan, Q.; Gao, L.; Cai, P.; Zhu, H.; Liu, R.; Wang, Y.; Wei, Y.; Huang, J.G.; Liang, X. Cytotoxicity and therapeutic effect of irinotecan combined with selenium nanoparticles. Biomaterials 2014, 35, 8854-8866. [CrossRef]

47. Shakibaie, M.; Shahverdi, A.R.; Faramarzi, M.A.; Hassanzadeh, G.R.; Rahimi, H.R.; Sabzevari, O. Acute and subacute toxicity of novel biogenic selenium nanoparticles in mice. Pharm. Biol. 2012, 51, 58-63. [CrossRef] [PubMed]

48. Yazdi, M.H.; Masoudifar, M.; Varastehmoradi, B.; Mohammadi, E.; Kheradmand, E.; Homayouni, S.; Shahverdi, A.R. Effect of oral supplementation of biogenic selenium nanoparticles on white blood cell profile of BALB/c mice and mice exposed to X-ray radiation. Avicenna J. Med. Biotechnol. 2013, 5, 158-167. [PubMed]

49. Raahati, Z.; Bakhshi, B.; Najar-peerayeh, S. Selenium Nanoparticles Induce Potent Protective Immune Responses against Vibrio cholerae WC Vaccine in a Mouse Model. J. Immunol. Res. 2020, 2020, 8874288. [CrossRef]

50. Zhang, J.; Wang, H.; Bao, Y.; Zhang, L. Nano red elemental selenium has no size effect in the induction of seleno-enzymes in both cultured cells and mice. Life Sci. 2004, 75, 237-244. [CrossRef]

51. Arslan, S.; Ozyurek, E.; Gunduz-Demir, C. A color and shape based algorithm for segmentation of white blood cells in peripheral bood and bone marrow images. Cytom. A 2014, 85, 480-490. [CrossRef] 